\title{
Determination of Reasonable Width of Filling Body for Gob-Side Entry Retaining in Mining Face With Large Cutting Height
}

\section{Shijiang Pu}

Guizhou University Mining College

Gui yi Wu (D827520903@qq.com)

Guizhou University Mining College

Qinzhi Liu

Guizhou University Mining College

Yuliang Wang

Guizhou University Mining College

Qiang Li

Guizhou University Mining College

Yu Xiong

Guizhou University Mining College

\section{Research Article}

Keywords: Mining face with large cutting height, Gob-side entry retaining, filling body, Reasonable width, Load-bearing structure

Posted Date: April 21st, 2021

DOI: https://doi.org/10.21203/rs.3.rs-423283/v1

License: (c) (1) This work is licensed under a Creative Commons Attribution 4.0 International License. Read Full License 


\title{
Determination of reasonable width of filling body for gob-side entry retaining in mining face with large cutting height
}

\author{
Shijiang Pu ${ }^{1}$; Guiyi $\mathrm{Wu}^{2}$; Qinzhi $\mathrm{Liu}^{3}$; Yuliang Wang ${ }^{4}$; Qiang $\mathrm{Li}^{5}$; Yu Xiong ${ }^{6}$ \\ ${ }^{1}$ Master of Engineering, Mining College of Guizhou university, Guiyang, Guizhou 550025, PR China. Email: \\ pu.sj@qq.com
}

${ }^{2}$ Associate Professor, Mining College of Guizhou university, Guiyang, Guizhou 550025, PR China(Corresponding author), Email: 827520903@qq.com

${ }^{3}$ Associate Professor, Mining College of Guizhou university, Guiyang, Guizhou 550025, PR China, Email: 39850741@qq.com

${ }^{4}$ Master of Engineering, Mining College of Guizhou university, Guiyang, Guizhou 550025, PR China. Email: 2665309329@qq.com

${ }^{5}$ Master of Engineering, Mining College of Guizhou university, Guiyang, Guizhou 550025, PR China. Email: 1185636205@qq.com

${ }^{6}$ Master of Engineering, Mining College of Guizhou university, Guiyang, Guizhou 550025, PR China. Email: 744561259@qq.com

\begin{abstract}
When gob-side entry retaining is adopted in mining face with large cutting height, due to large stope space, strong dynamic pressure and other reasons, the filling body is usually broken and unstable due to improper width of filling body, and the stability of surrounding rock of roadway is poor. Therefore, this paper will take Shaqu mine as the engineering background to study the reasonable filling body width of gob-side entry retaining in mining face with large cutting height. Firstly, the stability factors of gob-side entry retaining in mining face with large cutting height are analyzed, and the mechanical model of bearing structure of gob-side entry retaining is established based on the lateral pressure and overlying load of filling body, and the reasonable width of filling body is obtained quantitatively; Numerical simulation is used to analyze the evolution of vertical stress, vertical displacement and plastic zone of working face with the change of filling body width. Finally, combined with the deformation observation results of 24207 gob-side entry retaining roof, two sides and filling body, the rationality of filling body width is verified. The results show that: the setting of the width and strength of the filling body plays an important role in the stability of gob-side entry retaining. According to the mechanical model, the minimum width of the filling body is $2.2 \mathrm{~m}$ in the lateral direction and $3.9 \mathrm{~m}$ in the vertical direction; Numerical simulation shows that when the width of filling body is too small, with the increase of filling body width, the vertical stress of filling body increases gradually. When the width of filling body reaches a certain value, the vertical stress decreases with the increase of width, and the stress concentration area will change from symmetrical type to eccentric load type, from the middle of filling body to the side of filling body near gob. If the width of the filling body is too small, the filling body will be too broken to bear the load, resulting in too small vertical stress and too large vertical displacement of the roadway roof. The larger the width of the filling body is, the greater the cutting resistance is, the more timely the side roof of the gob can be cut off, the less the stress of the roadway and the filling body, and the more stable the retained
\end{abstract}


roadway is. Finally, through the observation of 24207 gob-side entry retaining, the total deformation of two sides and roof and floor of roadway tends to be stable after $665 \mathrm{~mm}$ and $597 \mathrm{~mm}$ respectively. The roof of roadway does not appear severe subsidence and obvious cracking, and the floor does not appear too large floor heave. The effect of roadway retaining is good, which indicates that $4 \mathrm{~m}$ support can meet the needs of practical engineering.

Key words: Mining face with large cutting height, Gob-side entry retaining, filling body, Reasonable width, Loadbearing structure

\section{Introduction}

In recent years, in order to reduce the waste of resource, coal pillar-free mining technology is more and more popular in China, which is not only good for improving production rate of mining area, relieving the tension of replacement, resolving the problem of gas accumulation and so on, but also has active effect on the prevention of coal spontaneous combustion, impact pressure(He et al. 2015; Zhang et al. 2020a). Gob-side entry retaining is generally used to mine coal pillar-free mining method, its main idea is to maintain a section of the roadway for using in the next section, according to the different roadway protection ways, roadway retention can be divided into the filling body of gobside entry retaining and gob-side entry retaining by cutting roof, the two ways under different geological type have own advantages, usually according to different engineering background to choose the suitable way(Su et al. 2015; Gao et al. 2019).

Due to the characteristics of large stope space and strong dynamic pressure, many difficult support problems often appear when filling body of gob-side entry retaining in mining face with large cutting height(Kong et al. 2019; Lou et al. 2017,2021). In the case of unreasonable parameter setting of filling body in the early stage, the roof of roadway is often prone to large-scale, and the number of renovations is more, which seriously hinders the working of coal mining face(Lou et al. 2019; Kang et al. 2011). The determination of filling body strength, width and other factors has always been an important condition to be determined at the beginning of the project. Reasonable filling body retention can not only achieve higher economic benefits, but also bring more stable bearing effect to the loadbearing system of filling body along the roadway, and it is also more favorable to the control of surrounding rock of the roadway(Cheng et al. 2019; Zhang et al. 2019a; Chang et al. 2018).

Based on this, many scholars carry out relevant research on gob-side entry retaining in mining face with large cutting height. It is generally believed that reasonable length width ratio of filling body can greatly increase the yield area and reduce the damage degree of roadway. Different widths of filling body bear different compressive stress, and the compressive stress will tend to be stable when the width reaches a certain value(Han et al. 2019; Sun et al. 2019; Cheng et al. 2020). Appropriate strength of filling body can not only relieve roof pressure and strong impact load, but also increase support resistance and prevent filling from being crushed(Kong et al. 2021; Ning et al. 2014; Zhou et al. 2012; Xie et al. 2020). Zhang et al. (2020b) through uniaxial compression test and AE test, compared the post-peak performance of high water content material samples and concrete samples, and the results showed that the internal damage of high water content material samples was very slow in the post-peak stage, and the damage was much smaller than that of concrete samples.

The above provides a lot of reference for setting the parameters of filling body in the initial stage of gob-side entry retention. In terms of initial entry retention, many scholars have focused on the width and strength of filling body to ensure the stability of gob-side entry retention. When the strength material selection of filling body has been determined, the width setting of filling has become a research hotspot. But according to the current research and practice, most scholars only qualitatively analyzed the relationship between the width of the filling body and the support resistance, indicating that the larger the width of the filling body is, the higher the support resistance can be 
provided. However, there is little research on the stress change of the filling body and the deformation law of the surrounding rock of the roadway. And in the preliminary calculation of the width of filling body should be set, through the tedious calculation formula can only deduce a large range. Therefore, this paper will take Shaqu mine as the research background, from a pack of lateral pressure and overlying load, the bearing structure for building along the mechanics model, researched on the relation between width of filling body and filling body stress, the determination of quantitative filling body minimum width, and uses the FLAC3D numerical simulation of different filling body evolution law of displacement and stress distribution, finally passed gob-side entry retention in shaqu coal mine engineering verification are given, so as to provide reference for similar projects.

\section{Working face profile}

Shaqu Mine is located in Lvliang City, Shanxi Province, China. Its main type of coal is coking coal, which is mined by close coal seam group, as shown in Figure 1. The gas content of coal seam in Shaqu mine is high, the gas emission is large during coal mining, the gas overrun phenomenon of coal mining face is frequent, which seriously threatens the safety production of mine. In order to implement Y-type ventilation roadway retention technology along gob, reduce gas accumulation phenomenon at working face, and realize greater utilization of resources, it is decided to adopt the technology along gob roadway retention technology at 24207 working face to create good conditions for safe and efficient mining at working face. The test roadway is 24207 working face belt roadway. The average dip Angle of the working face is $5^{\circ}$. The combined mining of $3+4 \#$ coal seam is between $3.85 \mathrm{~m}-4.36 \mathrm{~m}$ with an average thickness of $4.17 \mathrm{~m}$. The length of the belt roadway is $1692 \mathrm{~m}$, the length of the track roadway is $1688 \mathrm{~m}$, the length of the working face is $220 \mathrm{~m}$, and the mineable length is $1548 \mathrm{~m}$, as shown in Figure 2. The floor elevation of the working face is between $360 \mathrm{~m}$ and $450 \mathrm{~m}$, and the overlying surface of the working face is loess covered area with the ground elevation between $866 \mathrm{~m}$ and $1001 \mathrm{~m}$. The pseudo roof of the working face is not developed, and there is $0.2 \mathrm{~m}$ mudstone locally. The immediate roof of $3+4 \#$ coal is gray medium fine sandstone with a thickness of about $5 \mathrm{~m}$, the main roof is coarse sandstone with a thickness of about $5.5 \mathrm{~m}$, and the black mudstone with a thickness of about $9 \mathrm{~m}$. The immediate bottom of $3 \#+4 \#$ coal seam is gray medium sandstone with lumpy pyrite, the main bottom is about $2.5 \mathrm{~m}$ sandy mudstone, and then the immediate roof of $5 \#$ coal seam is $0.6 \mathrm{~m}$ carbonaceous mudstone.

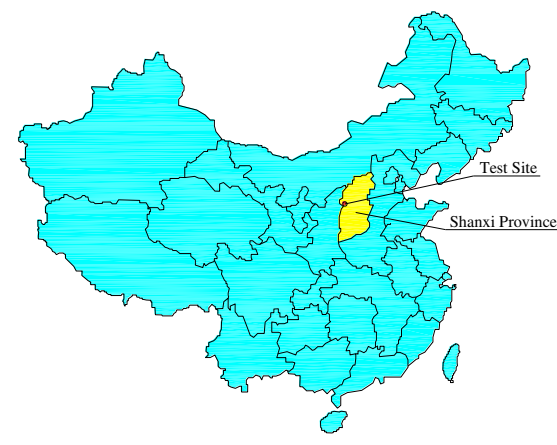

Figure 1. Geographical situation

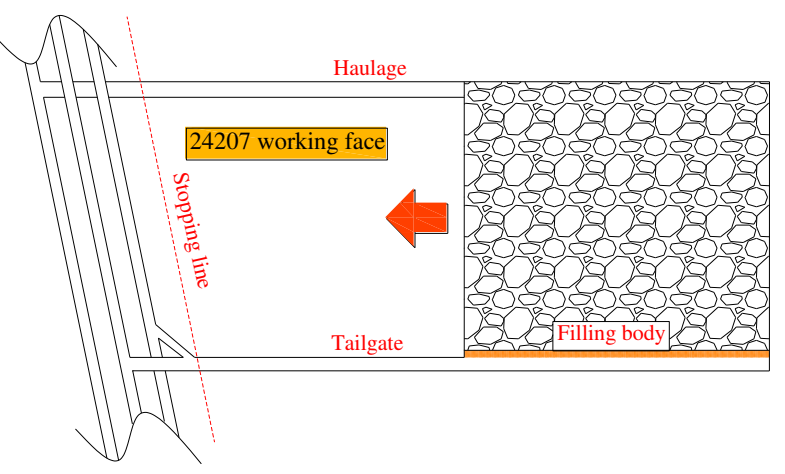

Figure 2. Working face layout

\section{Analysis of bearing stability of roadside filling body with mining face with large cutting height}

\subsection{Analysis of influence factors of stability}

There are many factors affecting the stability of surrounding rock of filling body of gob-side entry retaining. Gu et 
al. (2019) and Wu et al. (2020) conducted an experimental study on the roof of gob-side entry retention, and believed that the weak stability of surrounding rock supporting structure and the low lateral cooperative bearing capacity of the roof were the subjective reasons for the deformation and failure of surrounding rock of gob-side entry retention. In order to evaluate the adaptability of gob-side entry retention, Yang et al. (2016) analyzed the weight of each influencing factor under different conditions from geological factors such as coal seam dip Angle, mining height, overburden thickness, immediate roof thickness, immediate roof lithology and roof integrity, and showed that mining height had a great influence on the stability of gob-side entry retention. Of overburden stratum at the mining height are broken decision with activity space, the caving height, and height is greater with the increase of mining height are broken fissure zone, and the support system on the force source of basic load from the fractured zone rock, so the requirements under the conditions of different mining height are broken lane beside the support system of the support resistance is different also, with the increase of mining height are broken, filling the pressure also increased significantly, when mining height are broken over after more than a certain value, the support resistance will increase significantly, roof activity more influence to the stability of surrounding rock. So for mining face with large cutting height, necessary for the carrying capacity of the filling body and roadway on the auxiliary support put forward higher requirements.

The main influencing factors of gob-side entry retaining are the geometric characteristics or geological conditions of working face, which cannot be changed by human. In terms of retention and performance of filling body, reasonable support resistance can adapt to the severe deformation of gob-side entry retention, and it also requires fast resistance increase speed and low filling cost. However, when the strength of the filling body material is low and the stiffness is small, the bearing capacity of the filling body is limited, and the load of the overburden is mainly borne by coal, then the filling body has little influence on the lateral fracture law of the basic roof. When the filling materials on the strength and stiffness is bigger and has a certain width, overburden load shared by the mass media and the roadway beside filling body and roof coal and the pack on the structure of the two supporting function, key block B in coal side fracture location will change with the change of the support resistance on, when the immediate roof can be large enough transfer to main roof, the support resistance on the key block B may even occur at gob side secondary fracture (Feng et al., 2015; Zheng et al. 2019). In the case of different support resistances, the fracture positions of the main roof are mainly divided into the following three categories (Zhang, 2019b), as shown in Figure 3. Among them according to different parameters of filling body, the formation of the bearing structure within the support resistance is different, when filling body of support resistance and the real bearing capacity of coal is reasonable, the solid coal with filling physical carrying overburden load, and lateral cut overburden on filling body, at this time of roadway stability is best, as shown in figure 3 (c). The fracture position of the basic roof is not only related to lithology, coal seam dip angle and other geological factors, on the other hand, a major factor determining the fracture position of the basic roof is the parameter setting of the filling body. Therefore, the setting of filling body width and strength plays a crucial role in the stability of gob-side entry retention (Li et al. 2017; Sun et al.2020).

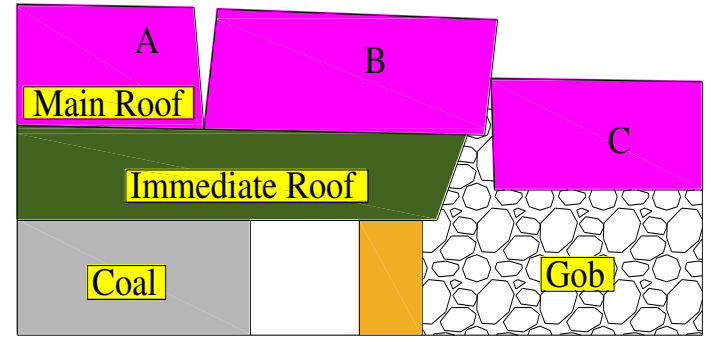

(a) The main roof fracture is above the solid coal body

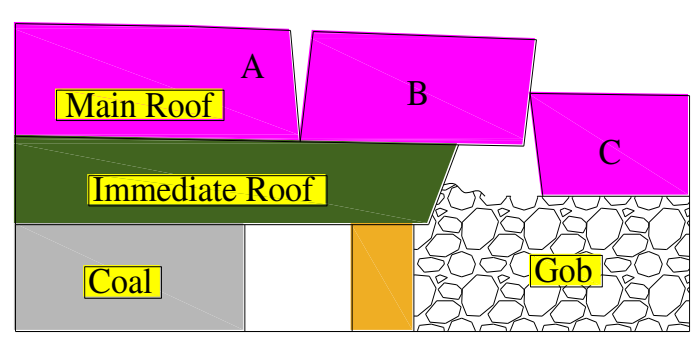

(b) The main roof fracture is above the roadway 

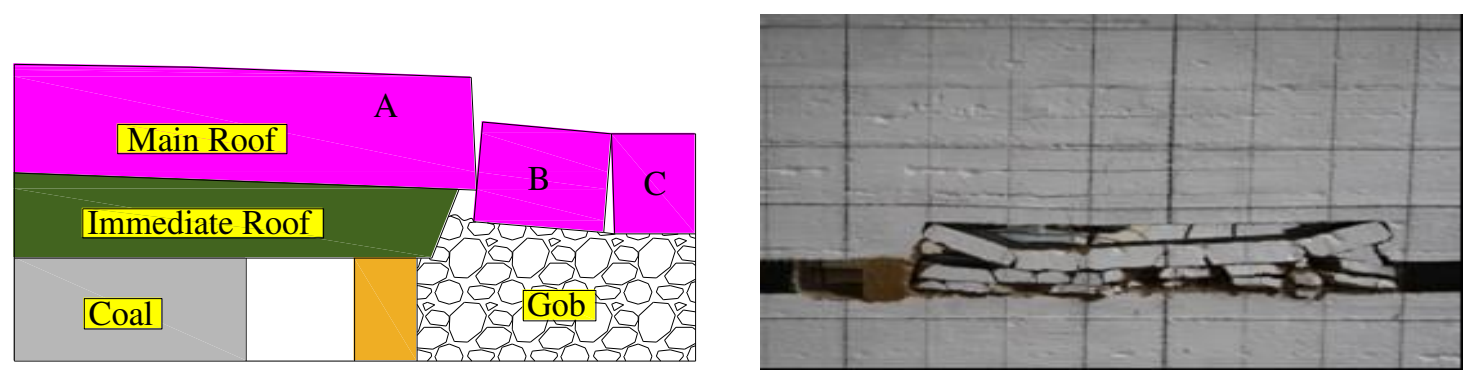

(c) The main roof fracture is located outside the filling body

Figure 3. Main top lateral fracture structure

\subsection{The determine of reasonable width of filling body}

After screening the filling materials of the roadway, it was decided to adopt CHCT paste concrete filling material for retaining the roadway, and then add $30 \mathrm{~mm}$ gravel. This method can increase the compressive strength of the filling material by about $30 \%$ and reduce the cost by about $15 \%$. Therefore, after determining the filling material, the final parameter that determines the performance of the filling body is the width of the filling body. As shown in Figure 3, the mechanical model of load-bearing structure of gob-side entry retention is established. The filling body beside the gob is mainly subjected to overburden load, friction force between the surrounding rock and lateral pressure provided by gangue caving in gob (Liu et al. 2020).

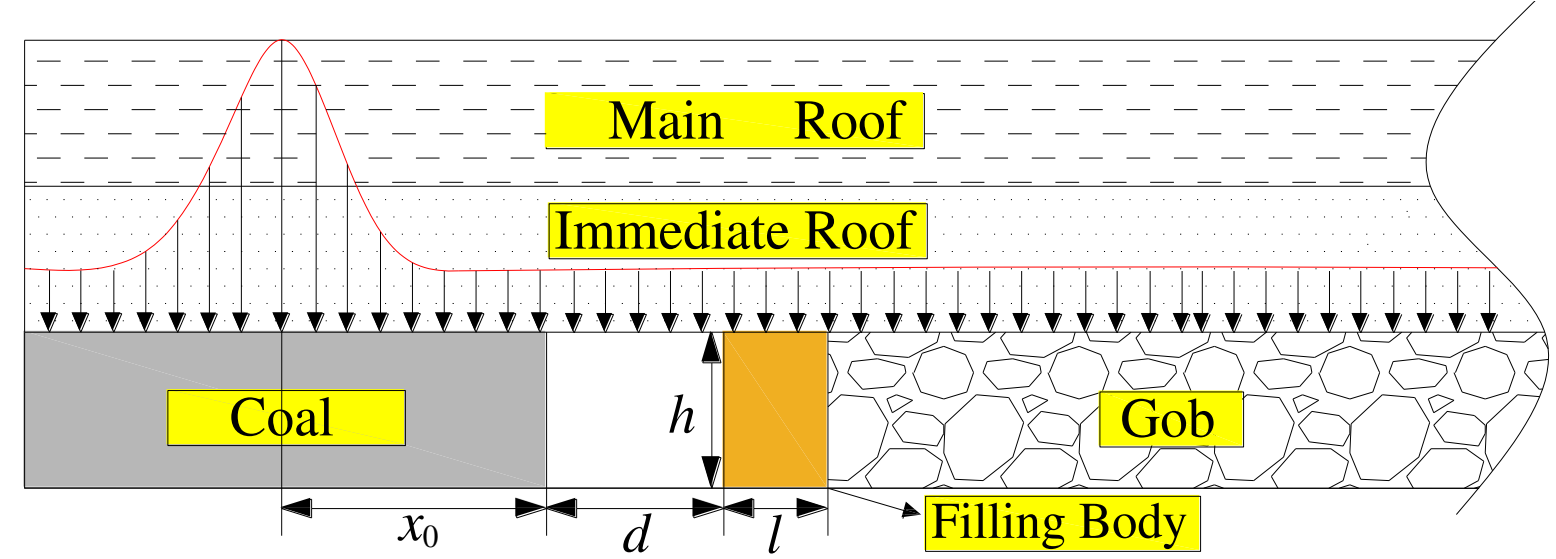

Figure 4. Mechanical model of bearing structure of gob-side entry retaining

1) Lateral stress analysis of filling body

Assumes that the gob caving coal gangue on the pack on force $\mathrm{F}$, and caving waste rock and filling body above the force for uniform load $Q, \beta$ is the bending angle of roof, the friction angle between filling body and top coal gangue is $\delta$. Under the condition of mining face with large cutting height, the mining space is large, the dynamic pressure is obvious, the immediate roof is easy to break, and the caving gangue at the bottom of the gob is easy to be compacted. Therefore, the gangue filling body can be approximately regarded as coarse-grain soil for calculation, and $F$ can be regarded as the pressure on the surface of the backfill body under the uniform distribution load of gangue. According to the geomechanical conditions, the force $F$ exerted on the filling body at this time is equivalent to the active earth pressure. The Coulomb earth pressure theory is used to calculate (Li et al. 2013), and then,

$$
F=\frac{1}{2} \gamma h_{1}^{2} K_{a}+h_{1} K_{a} Q \sec \beta
$$

Where: $\gamma$ is the average bulk density of filling gangue; $h_{l}$ is the height of filling body after compaction, $K_{a}$ Coulomb active earth pressure coefficient, and its value is: 


$$
\begin{gathered}
K_{a}=\frac{\cos ^{2} \varphi}{\cos \delta\left\{1+\left[\frac{\sin (\varphi+\delta) \sin \varphi}{\cos \delta}\right]^{\frac{1}{2}}\right\}^{2}} \\
h_{1}=h-\Delta h \\
\Delta h=\left(x_{0}+d+l\right) \tan \beta
\end{gathered}
$$

Where, $h$ is the filling height of the filling body, and $\varphi$ is the internal friction angle of the caved gangue. $\Delta h$ for compression deformation of gob side after filling compression, $d, l$ roadway width and filling body width respectively; $x_{0}$ is the distance between the bending base point of roof rock beam and the side of gob roadway, and its value is (Hou et al. 2001) :

$$
x_{0}=\frac{\lambda h}{2 \tan \varphi_{0}} \ln \left[\frac{k \gamma H+\frac{c_{0}}{\tan \varphi_{0}}}{\frac{c_{0}}{\tan \varphi_{0}}+\frac{p_{0}}{\lambda}}\right]
$$

Where, $\lambda$ is the lateral pressure coefficient, and 0.36 is taken according to Poisson's ratio; $\varphi_{0}$ and $c_{0}$ are the internal friction angle and cohesion of the interface between coal seam and roof and floor respectively, taking $28^{\circ}$ and $2 \mathrm{MPa} ; k$ is the stress concentration factor, which is $1.6 ; H$ is the buried depth of roadway, taking $529 \mathrm{~m} ; p_{0}$ is the coal support strength, and $2 \mathrm{MPa}$ is taken.

For the filling body, if it is to be stable, its friction force $f$ should meet the following requirements:

$$
f \geq F h_{1} \cos \delta
$$

The filling body is subjected to friction along the normal direction of the wall. In the case that the buried depth of the working face is large and the stress is large, the gravity action of the filling body can be ignored. Therefore, the friction force of the filling body can be approximated as:

$$
f=\mu\left(2 Q l+F h_{1} \sin \delta\right)
$$

Where: $\mu$ is the friction coefficient between the filling body and the roof and floor.

Equations (1) (6) are formulated together, and the function of filling body width under lateral pressure should meet the following requirements:

$$
l \geq \frac{F h_{1}(\cos \delta-\mu \sin \delta)}{2 \mu Q}
$$

The angle of $\beta$ is related to the filling rate of the filling area. According to the field experience, the Angle of $\beta$ is set as $8^{\circ}$. According to the field investigation of Shaqu mine, relevant parameters can be obtained as follows: $h$ $=4.2 \mathrm{~m}, \delta=30^{\circ}, \varphi=45^{\circ}, Q=3 \mathrm{MPa}, \mu=0.5, d=4 \mathrm{~m}$. The minimum width of backfill can be obtained as $2.2 \mathrm{~m}$ when applied into equation (7).

2) Analysis of overburden load on filling body

When the overlying strata are bent and deformed, the load on the filling body is regarded as the weight of the 
roof strata of the filling body, the roadway and the weak and broken part of the coal wall, which can be equivalent to the weight of $n=4 \sim 8$ times of the mining height (Han et al. 2014). Therefore, for the filling body with strength $q$, there is a certain value

$$
q \geq \frac{N\left(l+d+x_{0}\right) \gamma_{0} h}{l}
$$

The results are as follows

$$
l \geq \frac{N\left(d+x_{0}\right) \gamma_{0} h}{N \gamma_{0} h-q}
$$

Where, $\gamma_{0}$ is the volumetric force of the immediate roof, and $q$ is the initial strength of gob-side entry retaining filling body. According to the site conditions, $q$ takes $2 \mathrm{MPa}, N$ takes 4 , and substituting formula (9) to get the minimum width of the filling body is $3.9 \mathrm{~m}$.

To sum up, in addition to geological factors, the setting of filling body width and strength plays an important role in the stability of gob side entry retaining. Whether the filling body can remain stable mainly depends on the friction force of filling body in horizontal direction and the gravity load of overlying strata. Through comprehensive consideration of calculation, the minimum width of filling body should be $3.9 \mathrm{~m}$.

\section{Parameter determination of roadway side filling body}

According to the mechanical model of the bearing structure of gob-side entry retaining, it can be considered that the filling body has the same strength per unit length, and the pouring material of the filling body has been determined. Therefore, the final parameter determining the performance of the filling body is the width of the filling body. According to the actual situation of 24207 working face, FLAC3D is used to simulate the vertical stress, horizontal displacement and plastic zone distribution when the filling body width is $1 \mathrm{~m}, 2 \mathrm{~m}, 4 \mathrm{~m}, 6 \mathrm{~m}, 8 \mathrm{~m}$ and $10 \mathrm{~m}$ respectively. The calculation model as shown in Figure 5 is established, backfill body is set in the model in advance, and roadway is excavated first, followed by working face. The length, width and height of the model is $120 \mathrm{~m}, 100 \mathrm{~m}, 89 \mathrm{~m}$ respectively. A total of 18 coal beds have been established. The coal seam is near horizontal and the thickness of the coal seam is $4 \mathrm{~m}$. The bottom boundary of the model is fixed, that is, the displacement of the bottom boundary in $\mathrm{X}, \mathrm{Y}$ and $\mathrm{Z}$ directions is zero. The top of the model is a free boundary, and the equivalent load is applied to the upper strata. The self-weight load is set in the $\mathrm{Z}$-axis direction, and its value is $8.2 \mathrm{MPa}$. The Molar-Coulomb criterion is used for calculation. The mechanical parameters of rock mass used in numerical calculation are shown in Table 1. 


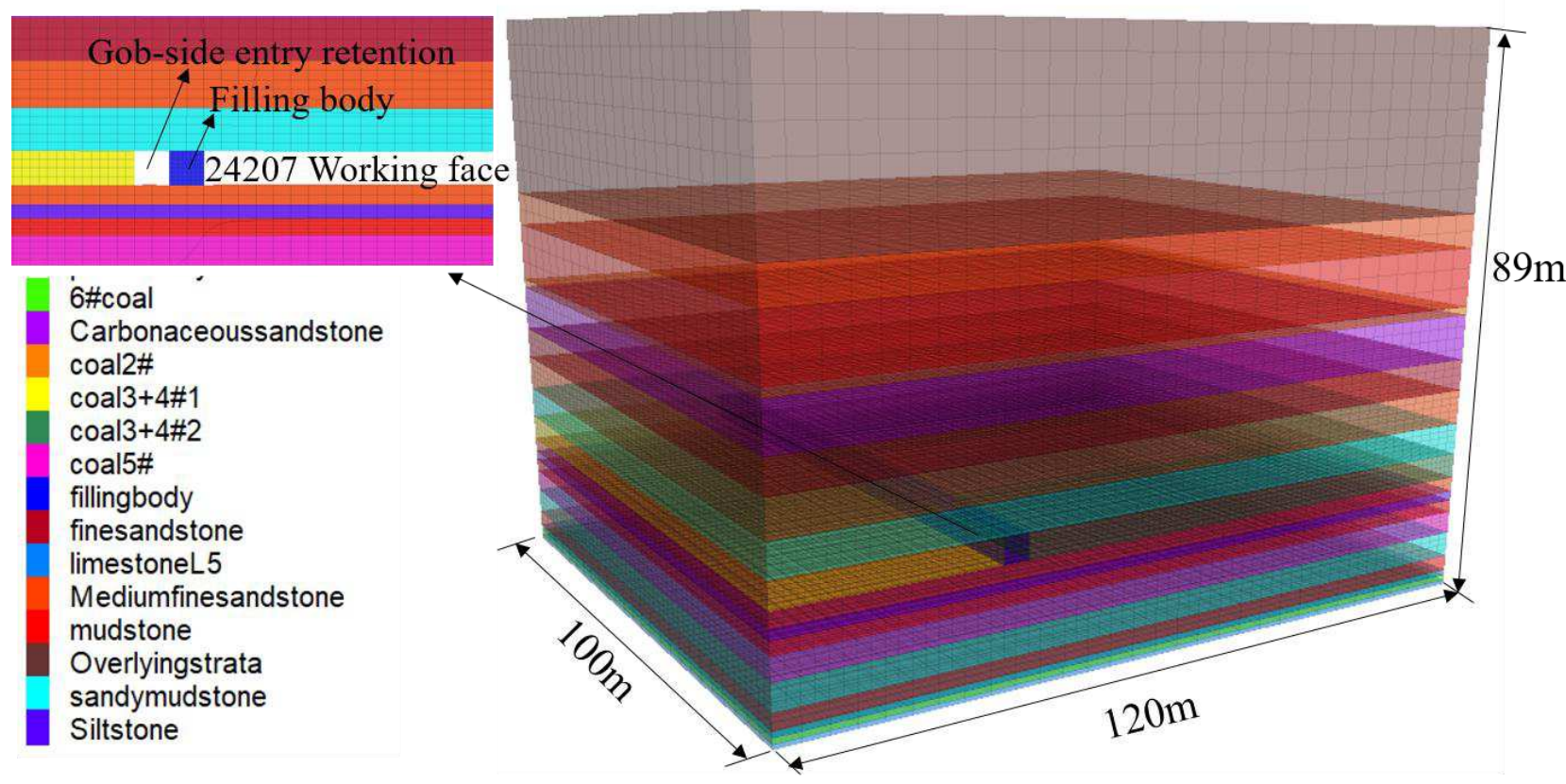

Figure 5. Numerical simulation model diagram

Tab.1 Mechanical parameters of rock mass

\begin{tabular}{ccccccc}
\hline Rock name & $\begin{array}{c}\text { Density } \\
\text { /kg.m }\end{array}$ & $\begin{array}{c}\text { Bulk } \\
\text { modulus } \\
\text { /Gpa }\end{array}$ & $\begin{array}{c}\text { Shear } \\
\text { modulus } \\
\text { /Gpa }\end{array}$ & $\begin{array}{c}\text { Cohesio } \\
\mathrm{n} / \mathrm{Mpa}\end{array}$ & $\begin{array}{c}\text { Tensile } \\
\text { strength } \\
\text { /Mpa }\end{array}$ & $\begin{array}{c}\text { Internal } \\
\text { friction angle } \\
\text { / }\end{array}$ \\
\hline Mudstone & 2350 & 2.10 & 1.95 & 1.5 & 1.400 & 32 \\
Fine-grained sandstone & 2600 & 1.89 & 1.20 & 8.3 & 1.252 & 35 \\
Coal 2\# & 1400 & 0.72 & 0.58 & 1.3 & 0.325 & 30 \\
Sandy mudstone & 2600 & 1.34 & 1.00 & 8.2 & 1.025 & 36 \\
Coal 3+4\# & 1400 & 1.44 & 1.38 & 1.3 & 0.200 & 30 \\
Siltstone & 2800 & 4.90 & 4.67 & 1.2 & 1.000 & 36 \\
Coal 5\# & 1400 & 1.44 & 1.38 & 1.3 & 0.200 & 30 \\
Limestone L5 & 2730 & 1.21 & 1.20 & 6.3 & 1.119 & 40 \\
Coal 6\# & 1400 & 1.44 & 1.38 & 1.3 & 0.200 & 30 \\
Medium sandstone & 2600 & 2.67 & 1.12 & 8.0 & 3.170 & 35 \\
Carbonaceous sandstone & 2520 & 1.86 & 1.15 & 1.4 & 1.790 & 33 \\
Filling body & 2950 & 2.60 & 1.70 & 3.0 & 1.650 & 34 \\
Overlying strata & 2500 & 2.28 & 1.80 & 6.0 & 1.550 & 33 \\
\hline
\end{tabular}

\subsection{Vertical stress analysis of different filling body width}

Figure 6 shows the vertical stress distribution diagram of filling body with different widths. As can be seen from the figure, with the increase of the width of the filling body, the vertical stress of the filling body increases gradually, and the stress of the roof above and the floor below the filling body also increases gradually. When the filling body width is $6 \sim 10 \mathrm{~m}$, the vertical stress of the filling body decreases with the increase of the filling body width, and the stress concentration area gradually changes from the symmetrical type when the filling body width is $1 \sim 4 \mathrm{~m}$ to the eccentric load type, that is, the stress concentration area changes from the middle part of the filling body when the filling body width is $1 \sim 4 \mathrm{~m}$ to the side of the filling body near the gob. This is because when the width of the filling body is too small, the resistance of the cutting top is too small to be a bearing body. The main roof breaks at the soild coal body side. Most of the force of the main roof when the main roof is rotated and sunk needs to be borne 
by the filling body. However, the over broken filling body cannot play the bearing capacity, which leads to the sharp asymmetric subsidence of the roof and filling body of the roadway. When the filling body is $1 \mathrm{~m}$, the filling body is the smallest, the overall maximum stress is only $18 \mathrm{Mpa}$, and the stress of roadway roof and floor is $4 \mathrm{MPa}$. At this time, it is very likely that the roadway roof has subsided violently and the filling body is seriously damaged. When the width of the filling body reaches a certain value, it can provide enough roof cutting resistance. At this time, the stress of the roof and floor of the roadway increases, and the filling body can cut off the roof of the gob side in time, so that the stress of the filling body decreases with the increase of the width, and the stress of the roof and floor of the roadway is normal.

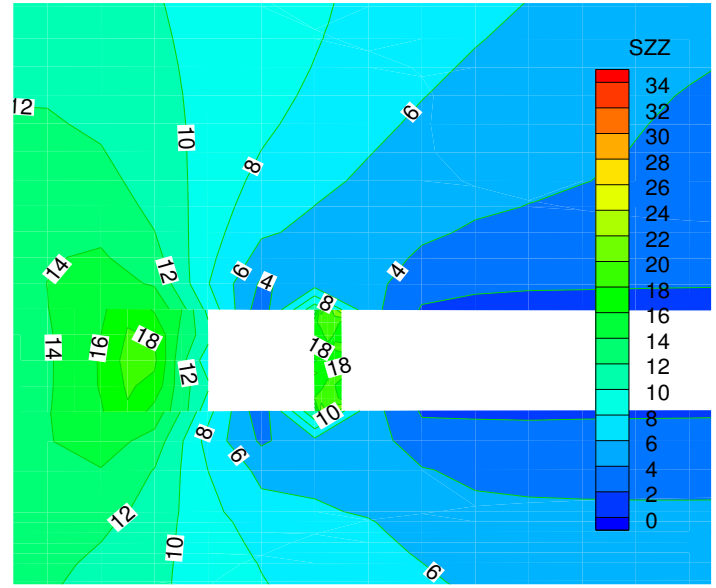

(a) $1 \mathrm{~m}$ filling body

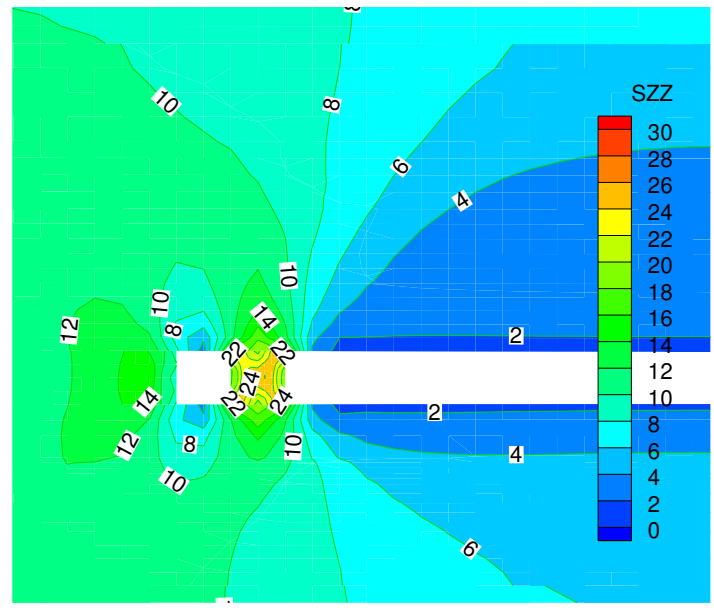

(c) $4 \mathrm{~m}$ filling body

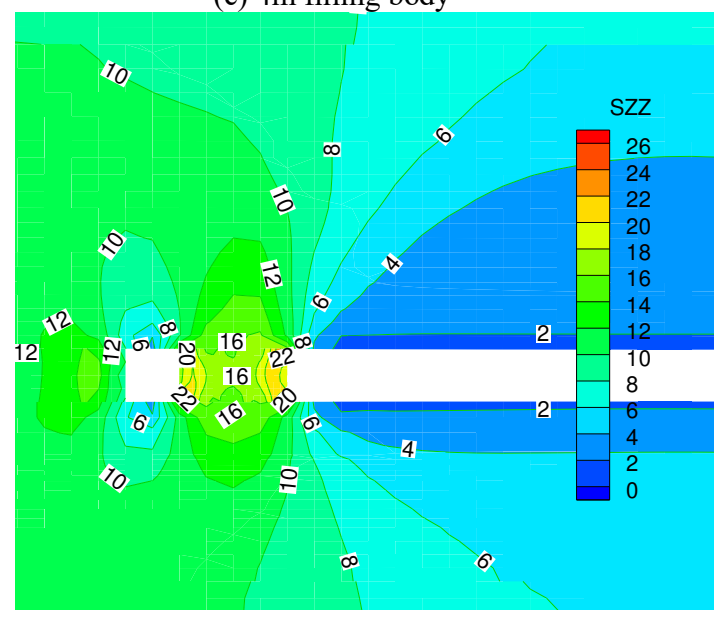

(e) $8 \mathrm{~m}$ filling body

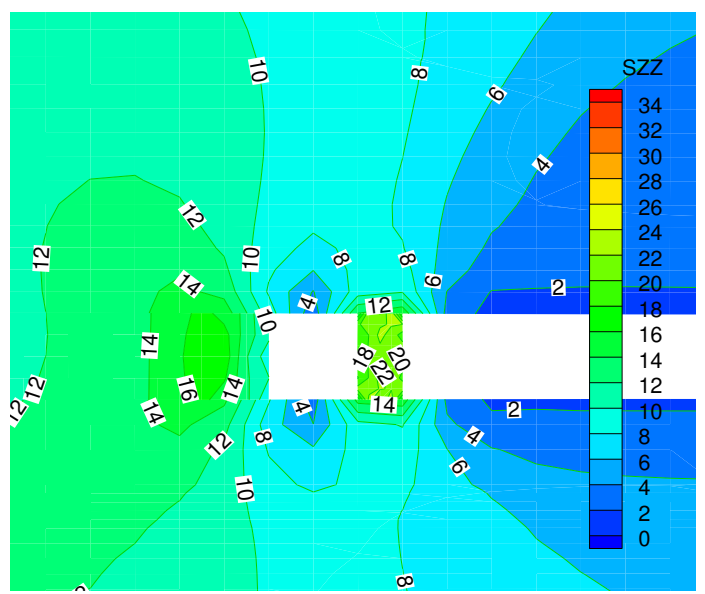

(b) $2 \mathrm{~m}$ filling body

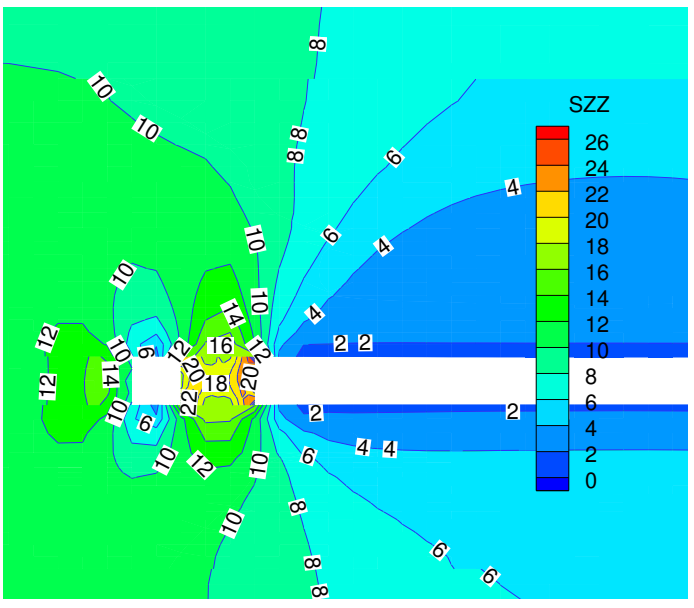

(d) $6 \mathrm{~m}$ filling body

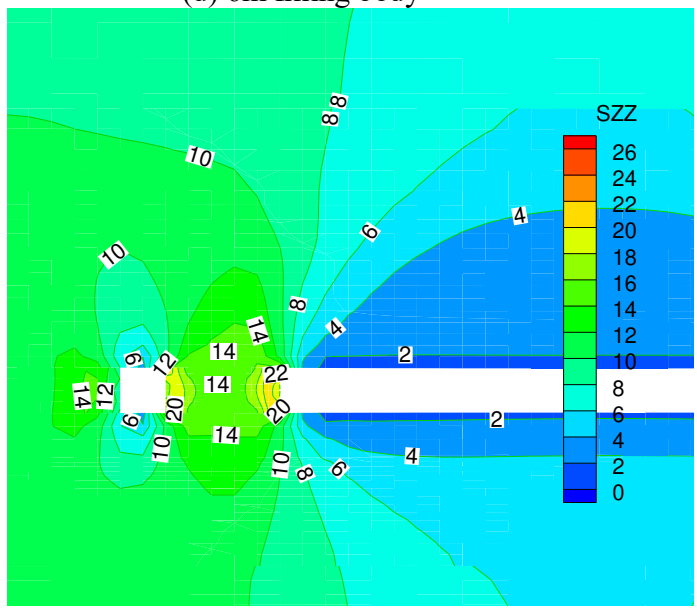

(f) $10 \mathrm{~m}$ filling body 
Figure 6. Vertical stress distribution of different filling body width

\subsection{Vertical displacement analysis of different filling body width}

Figure 7 shows the vertical displacement distribution diagram of backfill with different widths behind the working face. As can be seen from the figure, roof subsidence decreases gradually with the increase of filling body width. When the width of filling body is $1 \mathrm{~m}$, the maximum roof subsidence is $0.61 \mathrm{~m}$, the serious roof subsidence has occurred, and the asymmetric distribution of roadway deformation is obvious. The side subsidence of filling body is far greater than that of solid coal body, and the side subsidence of gob is also significantly greater than that of roadway. Because the width of the filling body is too small to form an effective bearing body, the filling body is seriously damaged, and the roof and filling body sink sharply, which is consistent with the stress analysis, and the roof is basically broken on the side of the solid coal body. When the width of the filling body is $2 \mathrm{~m}$, the roof subsidence of the roadway is still very large, the reason is the same as that when the width of the filling body is $1 \mathrm{~m}$, and the roadway and the filling body also have asymmetric deformation. When the width of the filling body is $4 \mathrm{~m}$, the roof subsidence decreases obviously compared with that of $1 \mathrm{~m}$ and $2 \mathrm{~m}$. At this time, the subsidence of the roadway and the filling body appears obvious symmetrical distribution. The subsidence in the middle of the roadway is the largest, and the two sides are slightly smaller, and the maximum subsidence is $0.38 \mathrm{~m}$. The subsidence in the middle of the filling body is the smallest, and the two sides are slightly larger, and the maximum subsidence of the filling body is $0.27 \mathrm{~m}$ In the controllable range, it shows that the filling body provides the appropriate cutting resistance at this time, which can cut off the roof on the side of the filling body in time, which is conducive to the stability of the roadway and the filling body. When the width of the filling body is $6-10 \mathrm{~m}$, the roof subsidence law is consistent with that of $4 \mathrm{~m}$, but it is not obvious that the subsidence of the roadway and the roof above the filling body is reduced.

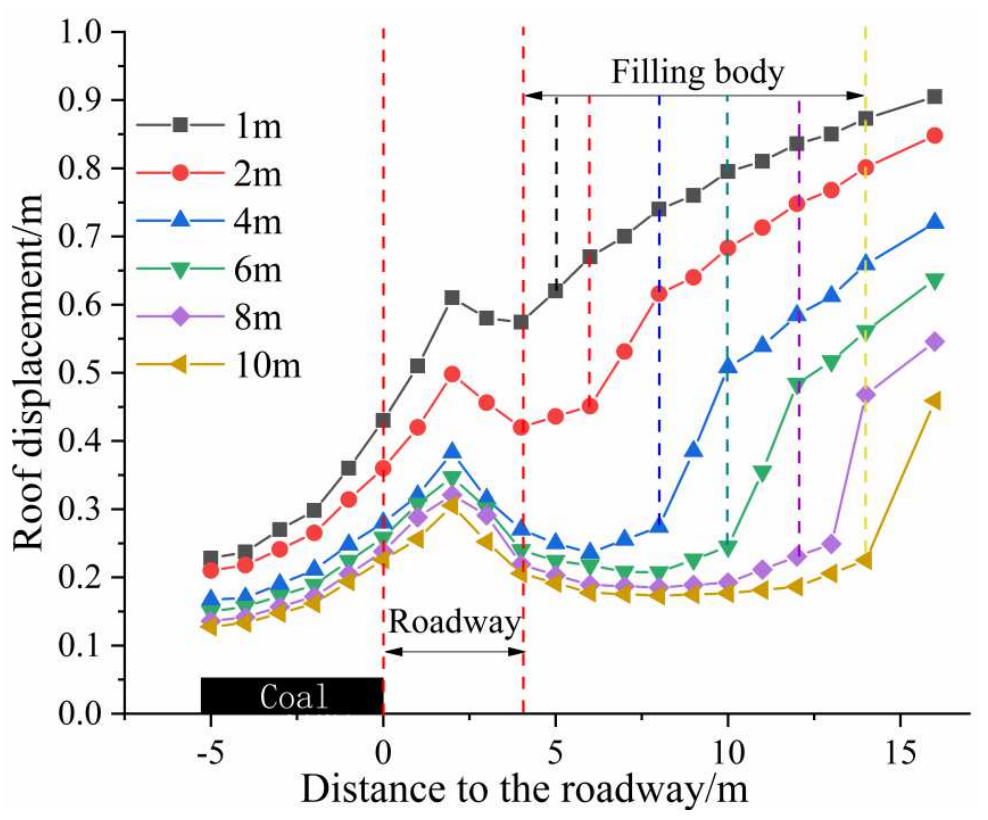

Figure 7. Vertical displacement distribution of filling body with different width behind working face

\subsection{Distribution of plastic zone of filling body with different width}

As shown in Figure 8, the distribution of plastic zone of filling body with different width is shown. It can be seen from the figure that when the filling body width is $1 \mathrm{~m}$ or $2 \mathrm{~m}$, the filling body has been completely damaged, and the surrounding rock deformation of the roadway is serious. When the width of the filling body is $4 \mathrm{~m}$, there is a small amount of plastic damage on both sides of the filling body, and most of the middle area is elastic area, which accounts for more than $80 \%$ of the whole filling body. When the width of the filling body is $4 \sim 6 \mathrm{~m}$, it can be seen that with the increase of the width of the filling body, the plastic area of the filling body is less, which fully proves 
that the increase of the width of the filling body is conducive to the stability of the roadside bearing structure.

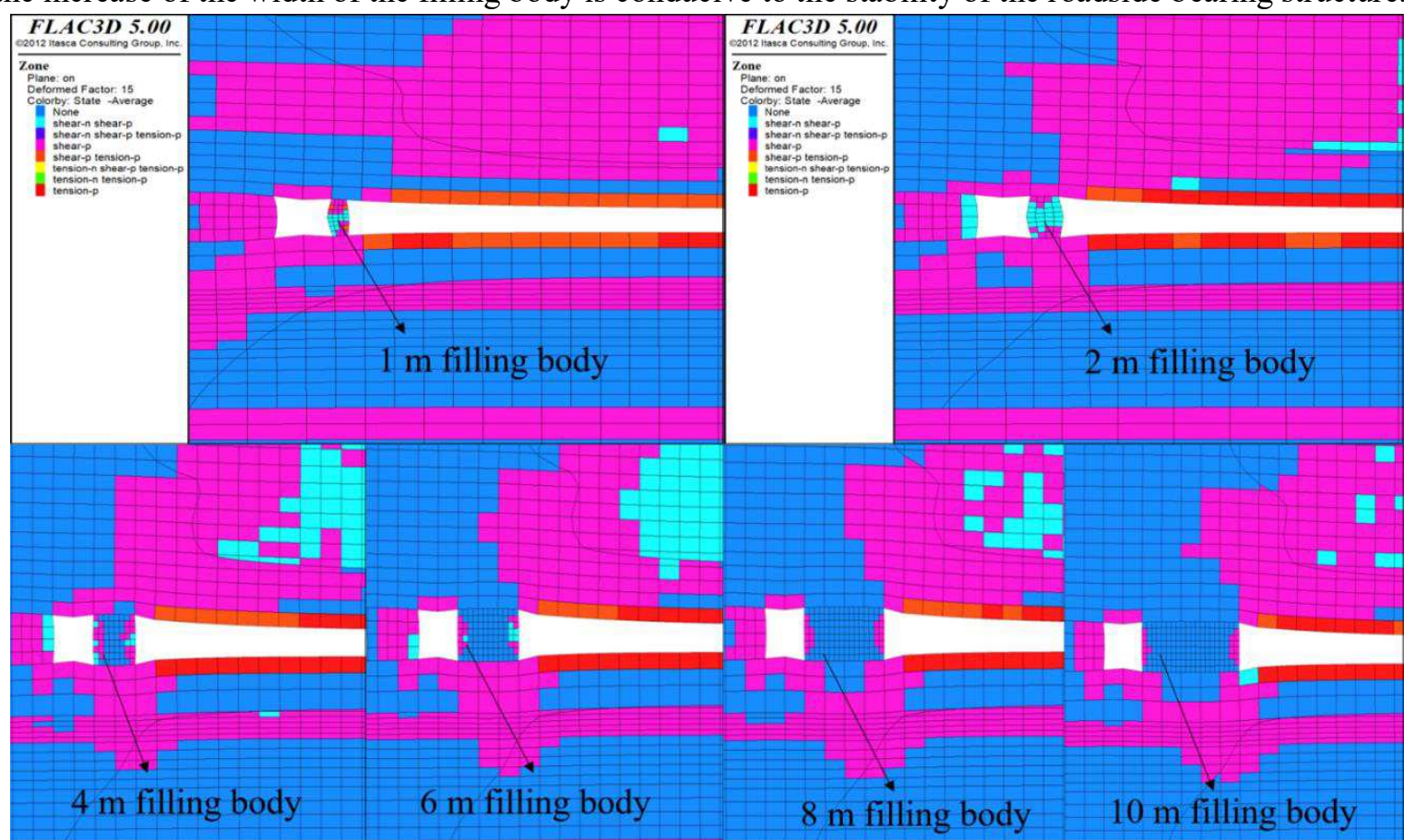

Figure 8. Distribution of plastic zone of different width filling body

Therefore, through the analysis of the distribution of vertical stress, vertical displacement and plastic zone in the working face, it can be concluded that if the width of the filling body is too small, the vertical stress of the filling body will be too small, and the vertical displacement of the roadway roof will be too large. This is because the filling body beside the roadway has been too broken to bear the load, which makes the roadway roof and filling body have serious asymmetric deformation. The larger the width of the filling body, the greater the cutting resistance, the more timely the roof of the gob side of the filling body can be cut off to reduce the stress on the roadway and above the filling body, and the more stable the retained roadway is. However, when the width of the filling body reaches a certain value, with the increase of the width of the filling body, the roof subsidence of the roadway has little change. Based on the above analysis and considering the economic cost, when the filling body width is $4 \mathrm{~m}$, the roadway deformation is within the controllable range, and the plastic failure range of the filling body is less, which has little difference with the theoretical calculation, and the economic cost of this scheme is lower, so the filling body width is selected as $4 \mathrm{~m}$.

\section{Field measurement}

Monitoring the support effect of filling body beside roadway is an important means to check the success of roadway retaining. According to the above analysis, the survey station layout of 24207 working face in Shaqu mine is carried out. The measuring station is arranged in the range of $0 \sim 260 \mathrm{~m}$ behind the working face. The observation work and mining are carried out simultaneously. When the filling length of the retained roadway reaches $220 \mathrm{~m}$, it is installed uniformly and observed in time. As shown in Figure 9, from the working face to $215 \mathrm{~m}$, the distance between $15 \mathrm{~m}$ and $30 \mathrm{~m}$ is not equal. A surface displacement measuring station is arranged, with 10 groups arranged, as shown in the figure, 1-10 \# each surface displacement measuring station is arranged with a comprehensive station, as shown in the figure 1, 3, 5 and 7. The comprehensive measuring station includes: one surface displacement measuring station, one roof off layer measuring station and one filling body deformation station. 


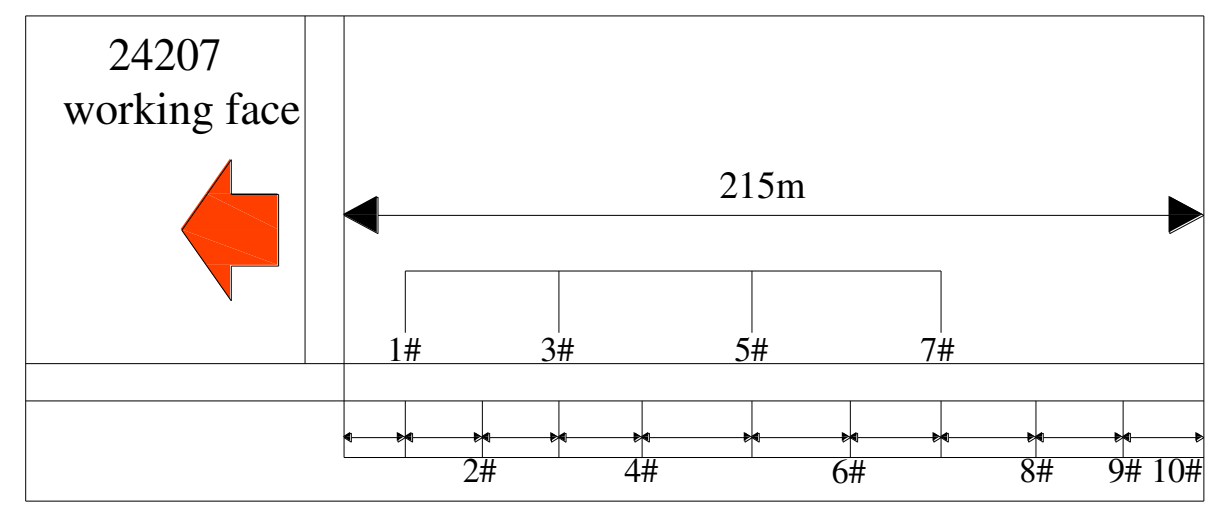

Figure 9. Layout of measuring station for 24207 gob-side entry retaining

The displacement of the roof and two sides of the gob-side entry retention of $4 \mathrm{~m}$ filling body at 24207 working face were monitored, and the rationality of the filling body was verified by analyzing the monitoring data. The monitoring results are shown in Figure 10 and Figure 11.

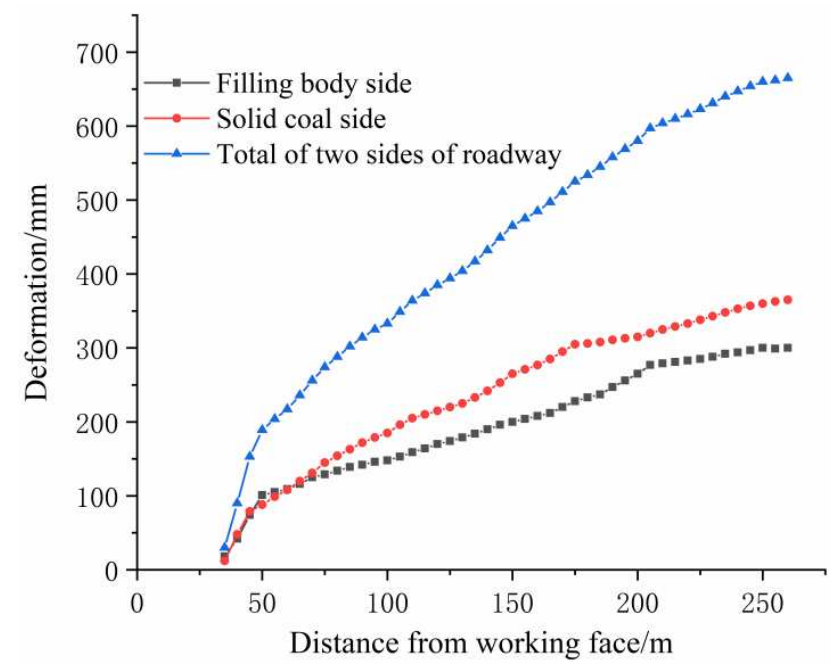

Figure 10. Deformation curve of two sides of 24207 gob-side entry retaining

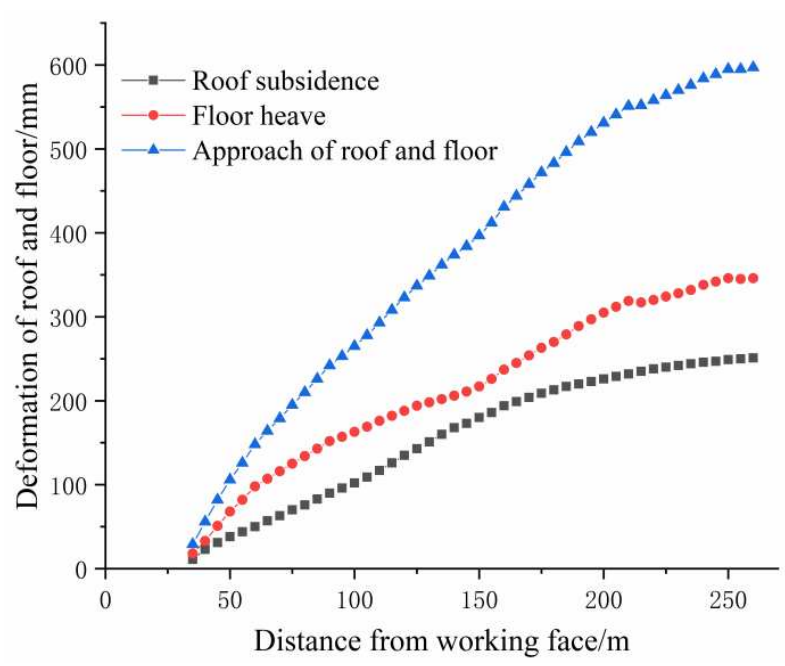

Figure 11. Curve of roof and floor deformation of 24207 gob-side entry retaining

As shown in Figure 10, 24207 gob-side entry retaining two side deformation curve, from the figure can be seen, with the farther away from the working face, the greater the deformation of roadway side. As shown in Figure 10, 24207 gob-side entry retaining two side deformation curve, from the figure can be seen, with the farther away from the working face, the greater the deformation of roadway side. The deformation rate of the two sides is the fastest at about $30 \sim 60 \mathrm{~m}$ behind the working face, and gradually decreases and tends to be stable after about $200 \mathrm{~m}$ behind the working face. The final deformation of the solid coal body side is $365 \mathrm{~mm}$, the final deformation on the filling body side is $300 \mathrm{~m}$, and the total deformation of the two sides is $665 \mathrm{~mm}$. The deformation of the side of the soild coal body accounts for $55 \%$ of the total deformation of the two sides, which indicates that the filling body beside the roadway keeps good integrity, and the deformation is mainly affected by the revolving subsidence of the roof.

As shown in Figure 11, 24207 gob-side entry retaining roof and floor deformation curve. It can be seen from the figure that the deformation of the roof and floor is slightly lower than that of the two sides. With the increase of the distance from the working face, the greater the deformation of the roof and floor is, and then tends to be stable. The final subsidence of the roof is $251 \mathrm{~mm}$, the final heave of the floor is $346 \mathrm{~mm}$, and the final approach of the roof and floor is $597 \mathrm{~mm}$. The deformation degree of the floor is greater than that of the roof, accounting for $58 \%$ of the 
total amount of the approach, which is in line with the deformation law of the surrounding rock of gob-side entry retaining. Moreover, the roof of the roadway has no severe subsidence and obvious cracking, and the floor has no excessive floor heave, indicating that the effect of roadway retaining is good.

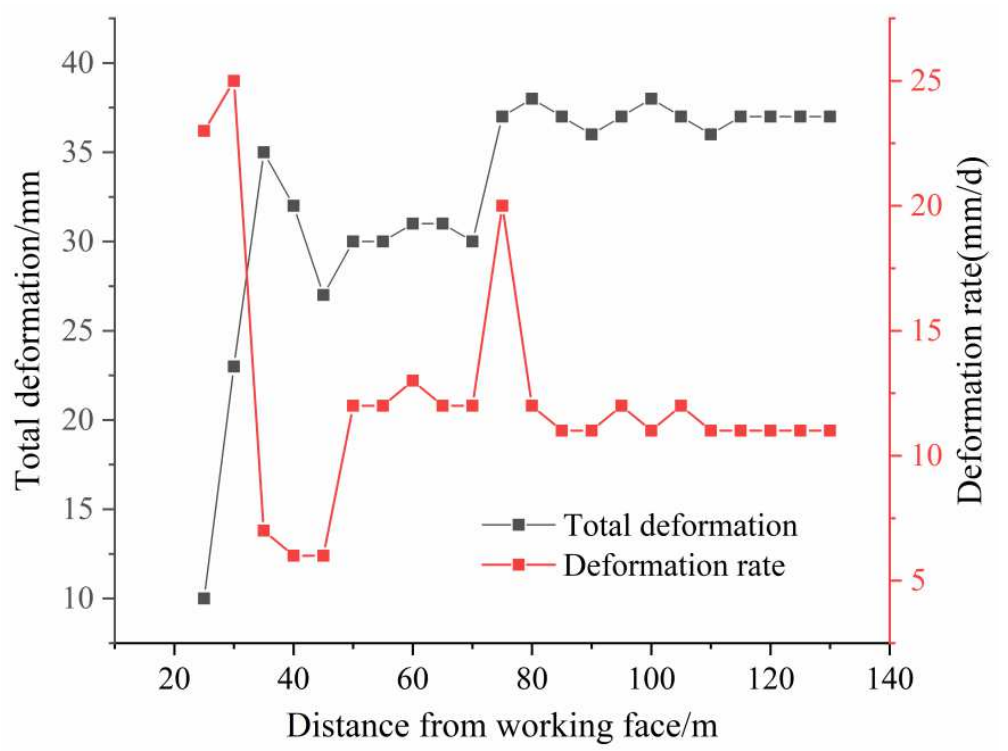

Figure 12. Relationship curve between deformation of filling body and distance from working face in 24207 gob-side entry retaining

As shown in Figure 12, the relationship between the deformation of filling body and the distance from the working face in gob side entry retaining is shown. In the figure, the left ordinate represents the cumulative deformation of filling body ( $\mathrm{mm}$ ), and the right ordinate represents the deformation velocity of filling body ( $\mathrm{mm} /$ d). It can be seen from the figure that the filling body has a large deformation in a short time after filling solidification, and the cumulative deformation has reached $32 \mathrm{~mm}$ at $35 \mathrm{~m}$ behind the working face, and the cumulative deformation after that is only $7 \mathrm{~mm}$. The deformation rate of the filling body has two large changes in the whole process. It shows that the filling body has two large deformations in a short time after filling and solidification. The filling body is greatly affected by the previous two periodic weighting of the working face, and then the deformation of the wall is not obvious with the stability of the overlying strata.

In summary, it can be seen that the total deformation of the two sides of the roadway and the roof and floor of the roadway tended to be stable after $665 \mathrm{~mm}$ and $597 \mathrm{~mm}$ respectively, and the deformation of the solid coal side accounted for $55 \%$ of the total deformation of the two sides, indicating that the backfill at the side of the roadway maintained a good integrity, and its deformation was mainly affected by the rotation and subsidence of the roof. The roof of the roadway did not appear sharp subsidence and obvious cracking, and the floor did not appear large floor heave. The effect of roadway retention was good.

\section{Conclusion}

(1) This paper analyzes the stability factors of gob-side entry retaining in mining face with large cutting height, and obtains the setting of filling body width and strength, which plays an important role in the stability of gob side entry retaining. Based on the lateral pressure and overlying load on the filling body, the mechanical model of the bearing structure of gob side entry retaining is established. The minimum width of the filling body is $2.2 \mathrm{~m}$ in the lateral direction and $3.9 \mathrm{~m}$ in the vertical direction. Finally, the minimum width of the filling body is determined to be $3.9 \mathrm{~m}$ by theoretical calculation.

(2) Using FLAC3D numerical simulation software analysis, when the width of the filling body is $1 \sim 4 \mathrm{~m}$, with the increase of the width of the filling body, the vertical stress of the filling body gradually increases; when 
the width of the filling body is $6 \sim 10 \mathrm{~m}$, with the increase of the width of the filling body, the vertical stress of the filling body decreases. At this time, the stress concentration area gradually changes from the symmetrical type of 1$4 \mathrm{~m}$ to the partial load type, from the middle of the filling body to the side of the filling body near the gob. When the width of the filling body is too small, the filling body has been over broken and cannot bear the bearing effect, resulting in serious asymmetric deformation of the roadway roof and the filling body, and the vertical displacement of the roadway roof is too large. The larger the width of the filling body is, the greater the cutting resistance is provided, the more timely the roof on the goaf side of the filling body can be cut off, the less the stress on the roadway and above the filling body, and the more stable the retained roadway is. Finally, when the filling body width is $4 \mathrm{~m}$, it can ensure the stability of surrounding rock and reduce the economic cost, which has little difference with the theoretical calculation.

(3) Through the observation of deformation of roof, two sides and filling body of 24207 gob-side entry retaining, it is found that the total deformation of two sides and roof and floor tends to be stable after $665 \mathrm{~mm}$ and $597 \mathrm{~mm}$ respectively, and the deformation of solid coal body side accounts for $55 \%$ of the total deformation of two sides, which indicates that the filling body beside the roadway maintains good integrity, the roadway roof does not appear severe subsidence and obvious cracking, and the floor does not appear excessive floor heave, The effect of retaining roadway is good, which shows that $4 \mathrm{~m}$ filling body can meet the needs of practical engineering, and verifies the correctness of theoretical analysis and numerical simulation.

Acknowledgements We acknowledge the financial support from the National Natural Science Foundation of China Youth Fund (No.51904082), the National Natural Science Foundation of China Regional fund (No. 52064005), and the funding from Guizhou Science and Technology Plan Project (Qianke Science Foundation [2020] 1y214).

\section{References}

Cheng ZB, Li LH, Zhang YN (2020) Laboratory investigation of the mechanical properties of coal-rock combined body, Bull of Eng Geol Environ 79:1947-1958.

Cheng Z, Yang S, Li L, Zhang L (2019) Support working resistance determined on top-coal caving face based on coal-rock combined body, Geomech and Eng 19(3): 255-268.

Chang CL, Tang WJ, Xu Y, Zhou HQ (2018) Research on the width of filling body in gob-side entry retaining with high-water materials. Int J Min Sci Techno 28(3): 519-524

Feng XW, Zhang N (2015) Position-optimization on retained entry and backfilling wall in gob-side entry retaining techniques. Int J of Coal Sci \& Techno 2(3):186-195.

Gu Q, Ru W, Tan Y, Xu Q (2019) Mechanical Analysis of Weakly Cemented Roof of Gob-side Entry Retaining in Fully-Mechanized Top Coal Caving Mining. Geotech Geol Eng 37(4):2977-2984

Gao YB, Wang YJ, Yang J, Zhang XY, He MC (2019) Meso- and macroeffects of roof split blasting on the stability of gateroad surroundings in an innovative nonpillar mining method. Tunn Undergr Sp Tech 90: 99-118

He MC, Zhu GL, Guo ZB (2015) Longwall mining "cutting cantilever beam theory" and 110 mining method in China-The third mining science innovation. J Rock Mech Geotech 7(5): 483-492

Han CL, Zhang N, Xue JH, Kan JG, Zhao YM (2019) Multiple and Long-Term Disturbance of Gob-Side Entry Retaining by Grouped Roof Collapse and an Innovative Adaptive Technology. Rock Mech Rock Eng 52(8):2761-2773

Hou CJ, Li XH (2001) Stability principle of large and small structure of surrounding rock in gob-side entry retaining in fully mechanized top coal caving face. [In Chinese.] J China Coal Soc 26(1):1-7 
Han CL, Zhang N, Li GC, Li BY, Wu H (2014) Stability analysis of compound bearing structure of gob-side entry retaining with large mining height. [In Chinese.] Chinese J of Geotech Eng 36(05):969-976

Kang HP, Wu YZ, Gao FQ (2011) Deformation characteristics and reinforcement technology for entry subjected to mining-induced stresses. J Rock Mech Geotech 3(3):207-219

Kong, DZ, Cheng, ZB Zheng SS (2019) Study on failure mechanism and stability control measures in large-cuttingheight coal mining face with deep-buried seam, Bulletin of Engineering Geology and the Environment 78(8): 6143-6157

Kong DZ, Pu SJ, Cheng ZH, Wu GY, Liu Y (2021) Coordinated Deformation Mechanism of the Top Coal and Filling Body of Gob-Side Entry Retaining in a Fully Mechanized Caving Face. Int J Geomech 21(4): 04021030

Lou JF, Kang HP, Gao FQ, Yang JH, Li JZ (2017) Determination of large - height support resistance based on multifactor analysis. [In Chinese.] J Chin Coal Soc 42(11): 2808-2816

Lou JF, Gao FQ, Yang JH, Ren TF, Li JZ, Wang XQ, Yang L (2021) Characteristics of evolution of mining-induced stress field in the longwall panel: insights from physical modeling. Int J Coal Sci Technol :1-18

Lou JF, Gao FQ, Li JZ, Yang JH, Wang XQ, Lei S (2019) Research and application of stress (pressure) measurement system for physical modeling. J Chin Coal Soc 44(S1): 31-40

Li YF, Hua XZ (2017) Mechanical analysis on the stability of surrounding rock structure of gob-side entry retaining. [In Chinese.] J of China Coal Soc 42(9):2262-2269

Liu X, Ji XZ, Miao KJ (2020) Stress characteristics and stability analysis of coal (rock) body in deep back-filling gob side entry. [In Chinese.] Journal of Mining \& Safety Engineering 37(01):32-39

Li GX, Zhang BY, Yu YZ (2013) Soil mechanics [M]. [In Chinese.] Beijing: Tsinghua University Press, 2013:10366

Ning JG, Wang J, Liu XS, Kun Q, Sun B (2014) Soft-strong supporting mechanism of gob-side entry retaining in deep coal seams threatened by rockburst. Int J Min Sci Techno 24(06):805-810

Su H, Bai JB, Yan S, Chen Y, Zhang ZZ (2015) Study on gob-side entry retaining in fully-mechanized longwall with top-coal caving and its application. Int J Min Sci Techno 25(3):503-510

Sun Q, Zhang J, Huang Y, Yin W (2019) Failure Mechanism and Deformation Characteristics of Gob-Side Entry Retaining in Solid Backfill Mining: A Case Study. Nat Resour Res $2: 1-15$

Sun X, Zhao C, Li G, Zhang B, Wang J, Cai F (2020) Physical model experiment and numerical analysis on innovative gob-side entry retaining with thick and hard roofs. Arab J of Geosci 13(23):1-16.

Wu JK, Zhou WB, Tao H, Bai HW, Yin W, Gu WH, Zhang P, Liu ZJ, and Zhang J (2020) Research on Failure Characteristics and Zoning Control Technology of Thick-Soft Surrounding Rock for Deep Gob-Side Entry Retaining. Shock Vib 2020: 6613514, 14

Xie SR, Pan H, Chen DD, Zeng JC, Song HZ, Cheng Q, Xiao HB, Yan ZQ, Li YH (2020) Stability analysis of integral load-bearing structure of surrounding rock of gob-side entry retention with flexible concrete formwork. Tunn Undergr Sp Tech 103:0886-7798

Yang HY, Cao SG, Wang SQ, Fan YC, Wang S, Chen XZ (2016) Adaptation assessment of gob-side entry retaining based on geological factors. Eng Geol 209:143-151

Zhang N, Yuan L, Han C, Xun J, Kan J (2020a) Stability and deformation of surrounding rock in pillarless gob-side entry retaining. Saf Sci 50(4):593-599

Zhang FT, Wang XY, Bai JB, Wang GY, Wu BW (2020b) Post-peak mechanical characteristics of the high-water material for backfilling the gob-side entry retaining: from experiment to field application. Arab J Geosci 13(7):183-186

Zhou B, Xu J, Zhao M, Zeng Q (2012) Stability study on filling body in gob-side entry retaining filled by falling gangue naturally. Int J Min Sci Techno 22(3):423-427. 
Zhang Z, Yu X, Deng M (2019a) Damage Evolution of Sandy Mudstone Mechanical Properties Under Mining Unloading Conditions in Gob-Side Entry Retaining. Geotech Geol Eng 37: 3535-3545

Zhang ML (2019b) Study on Mechanical Characteristics of Concrete Filling Body with Large Aspect Ratio and Stability of Surrounding Rock of gob-side entry retaining. [In Chinese.] Ph.D. thesis. Xuzhou, China: School of Mines, China Univ. of Mining and Technology.

Zheng W, Duan H (2019) Discussion on stability analysis and support technology of surrounding rock of gob-side entry retaining. J Vibroeng 21(4):1058-1068. 


\section{Figures}

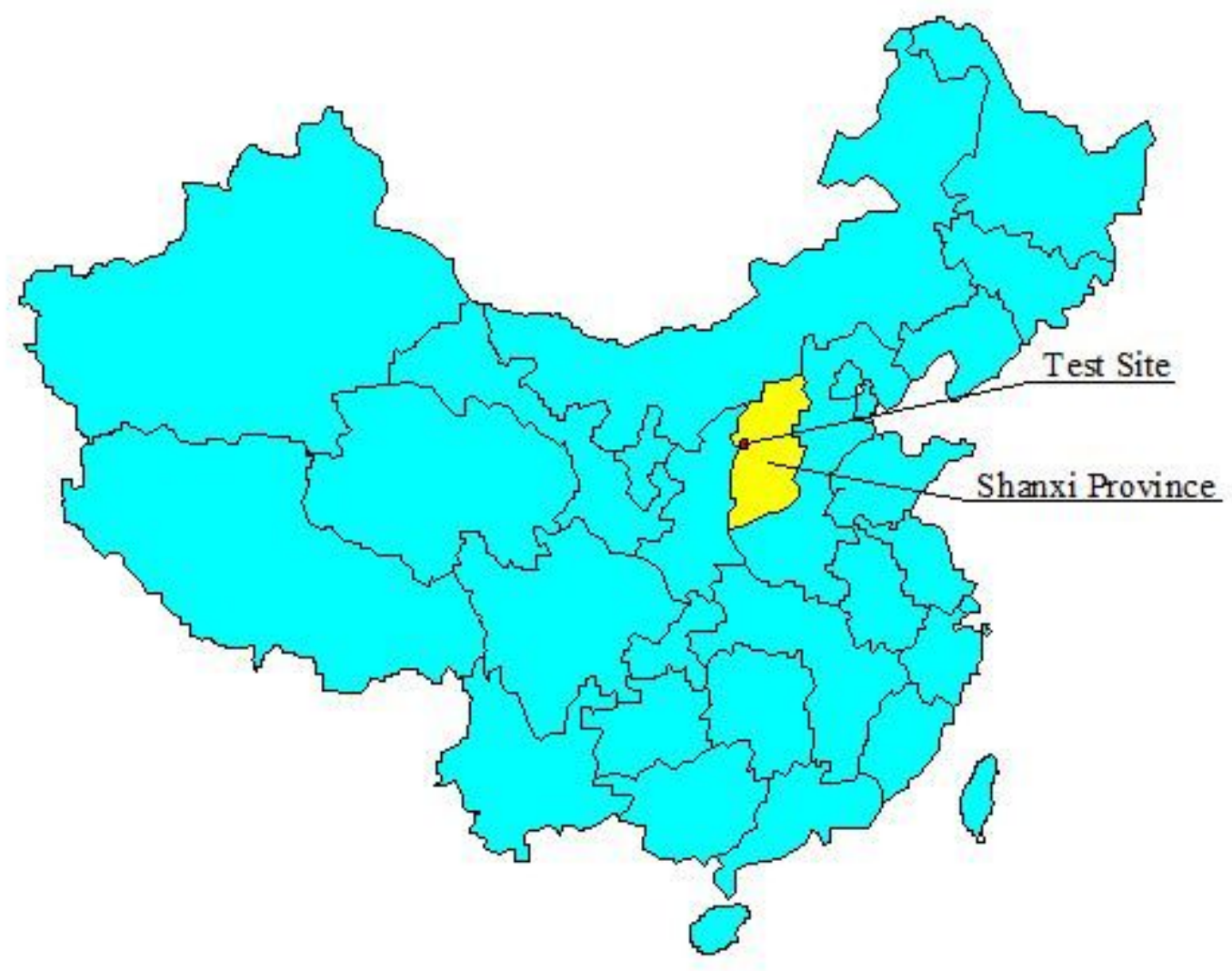

Figure 1

Geographical situation Note: The designations employed and the presentation of the material on this map do not imply the expression of any opinion whatsoever on the part of Research Square concerning the legal status of any country, territory, city or area or of its authorities, or concerning the delimitation of its frontiers or boundaries. This map has been provided by the authors. 


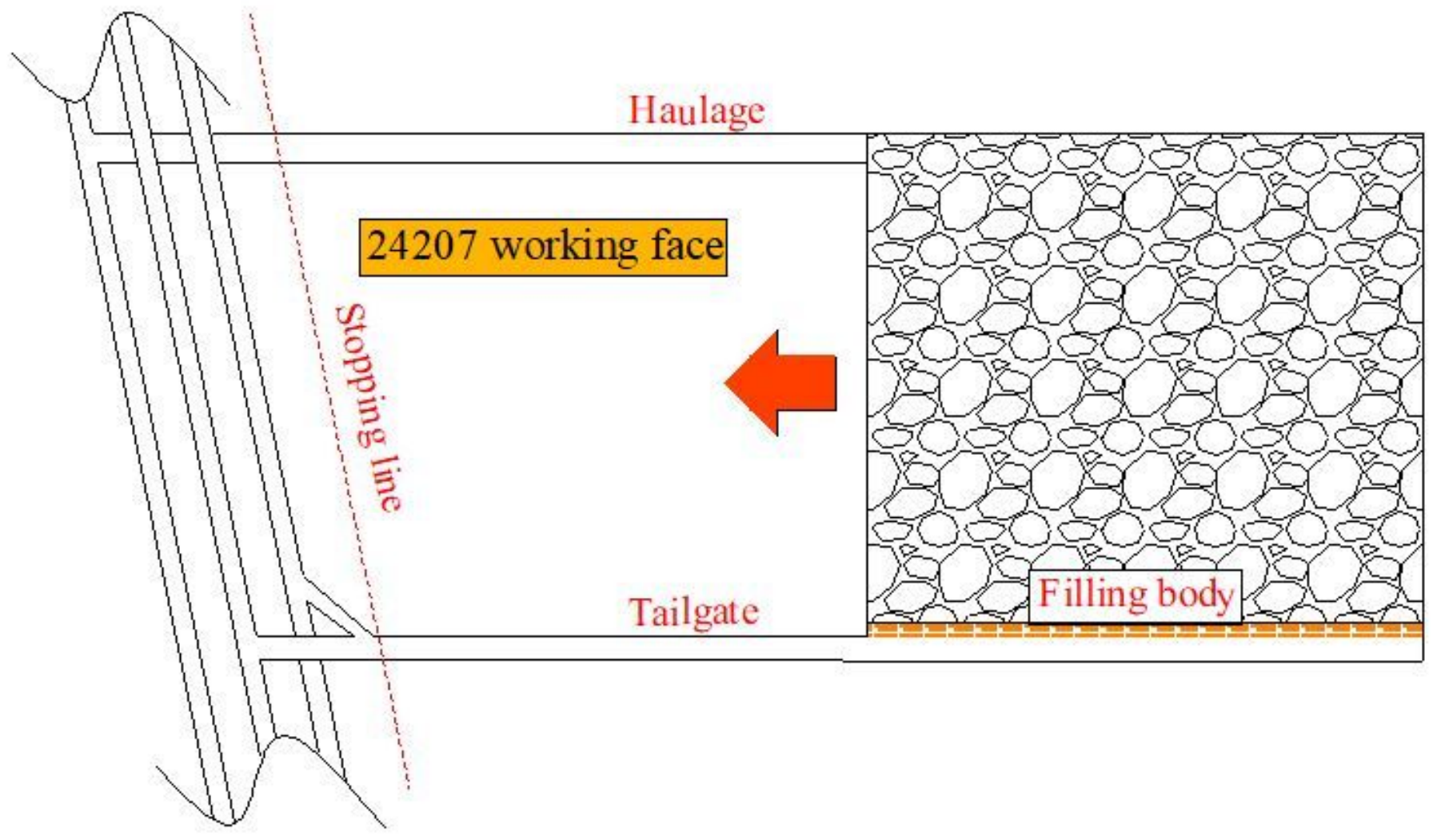

Figure 2

Working face layout

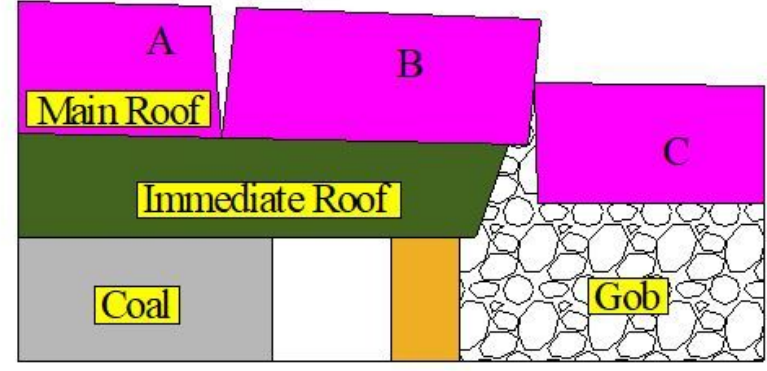

(a) The main roof fracture is above the solid coal body

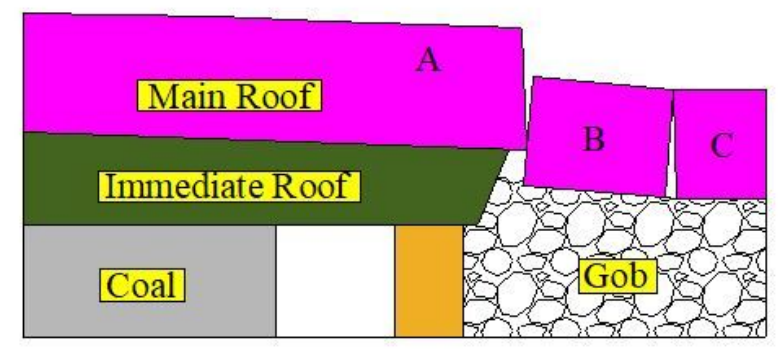

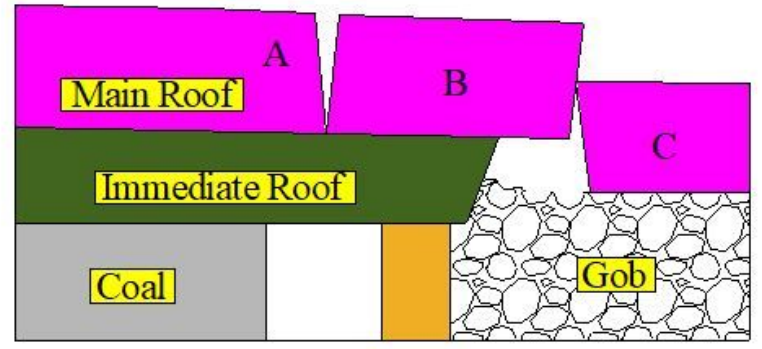

(b) The main roof fracture is above the roadway

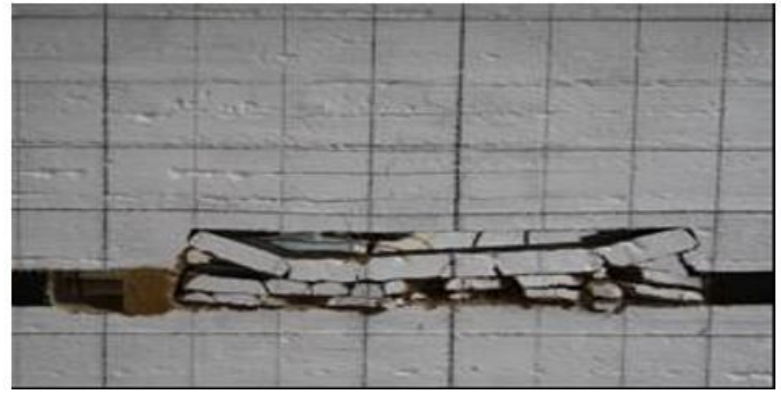

(c) The main roof fracture is located outside the filling body 


\section{Figure 3}

Main top lateral fracture structure

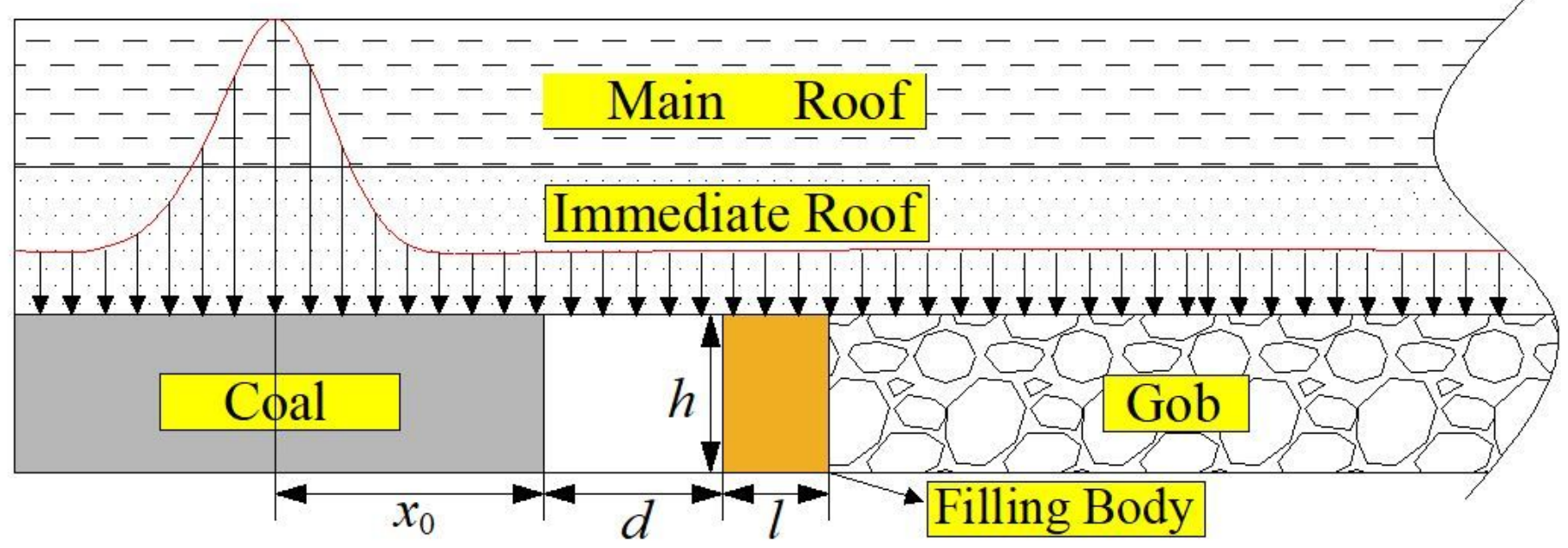

Figure 4

Mechanical model of bearing structure of gob-side entry retaining

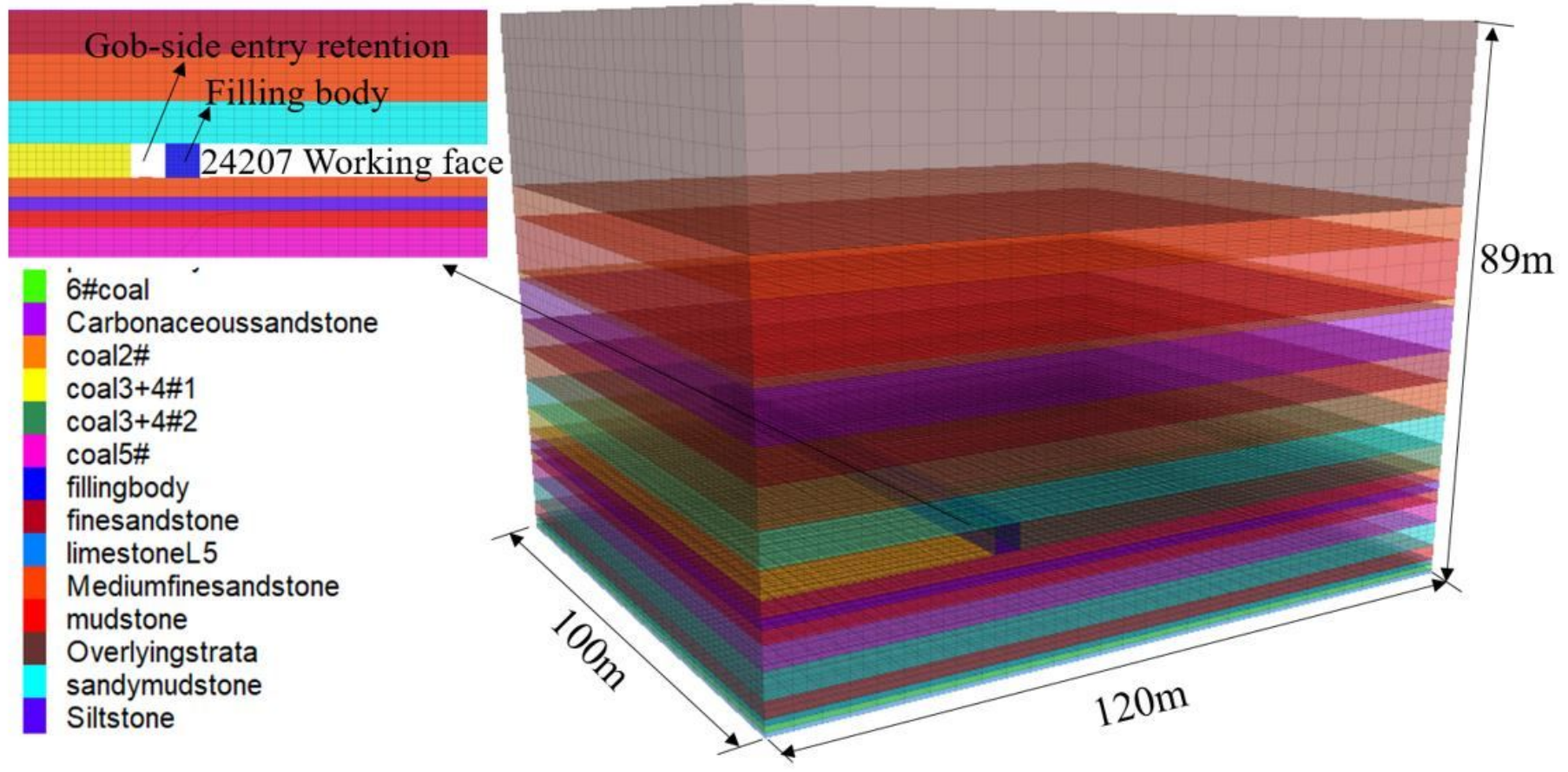

Figure 5

Numerical simulation model diagram 


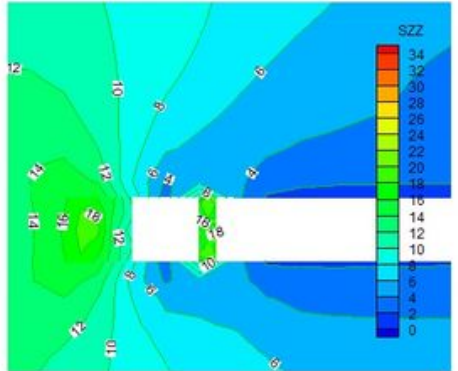

(a) $1 \mathrm{~m}$ filling body

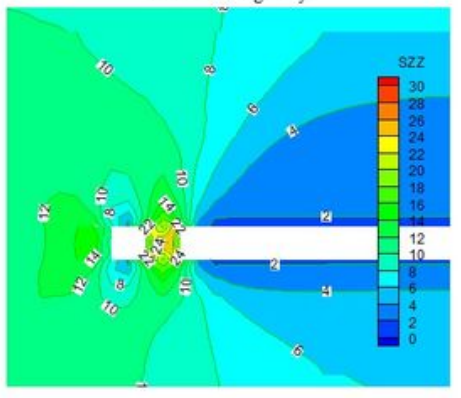

(a) $1 \mathrm{~m}$ filling body

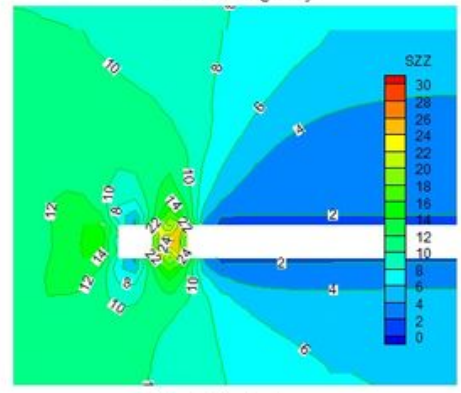

(c) $4 \mathrm{~m}$ filling body

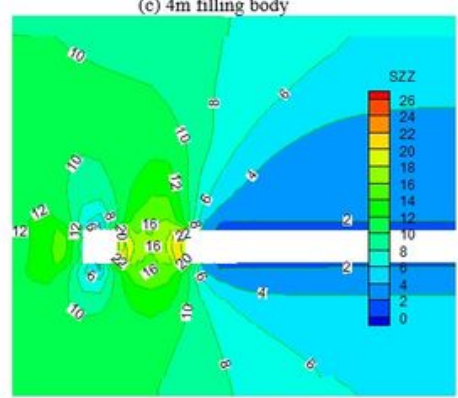

(e) $8 \mathrm{~m}$ filling body

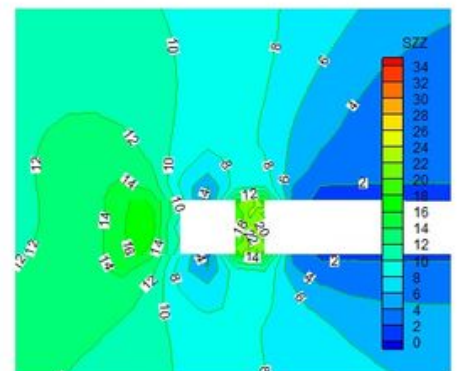

(b) $2 \mathrm{~m}$ filling body

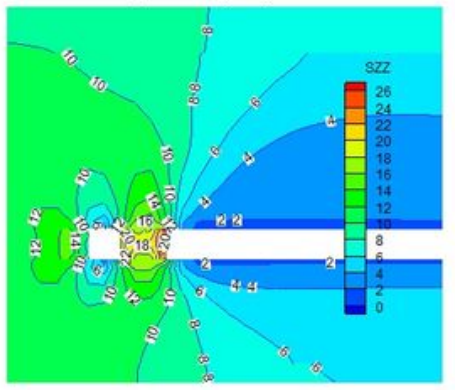

(b) $2 \mathrm{~m}$ filling body

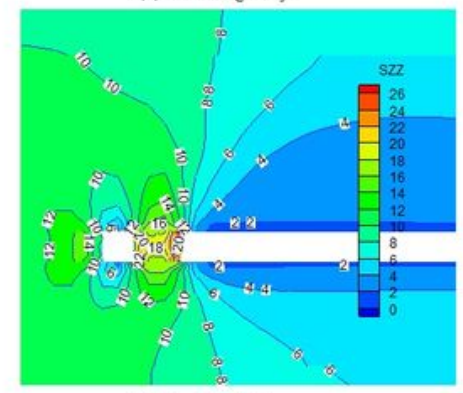

(d) $6 \mathrm{~m}$ filling body

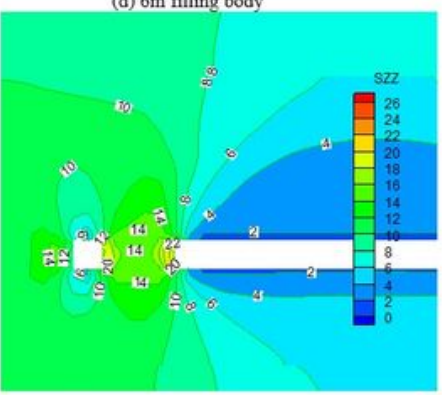

(f) $10 \mathrm{~m}$ filling body

\section{Figure 6}

Vertical stress distribution of different filling body width 


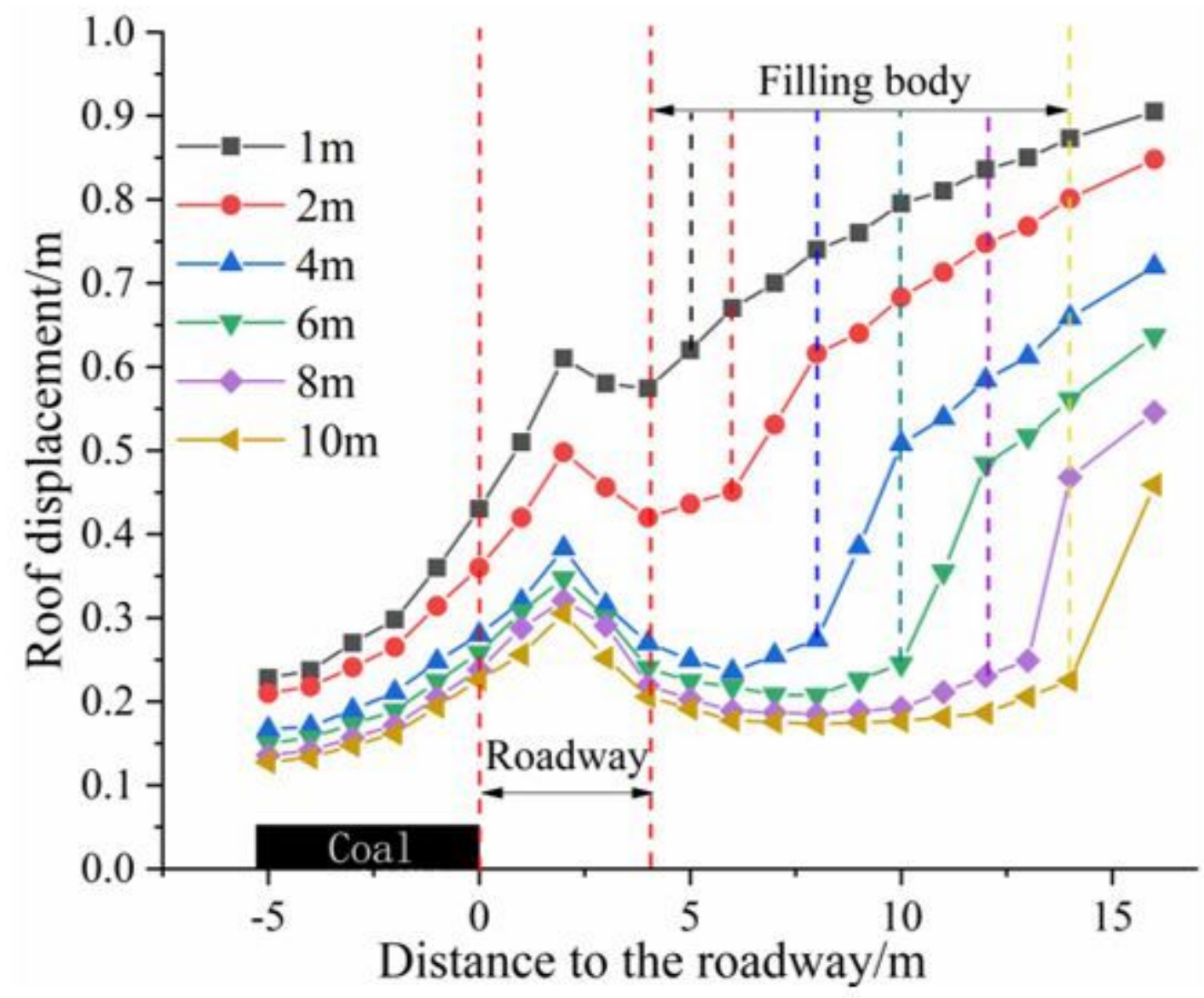

Figure 7

Vertical displacement distribution of filling body with different width behind working face 


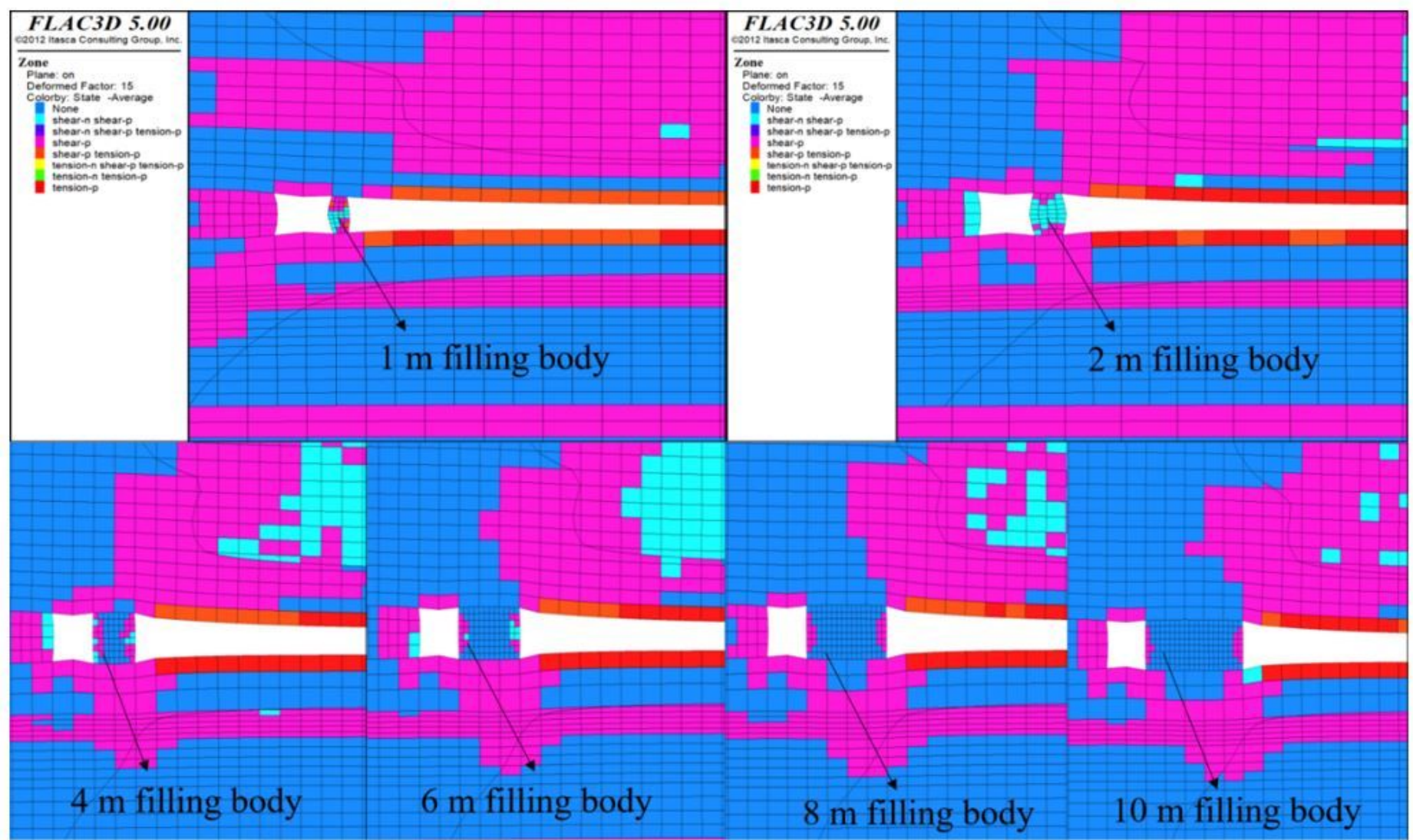

Figure 8

Distribution of plastic zone of different width filling body

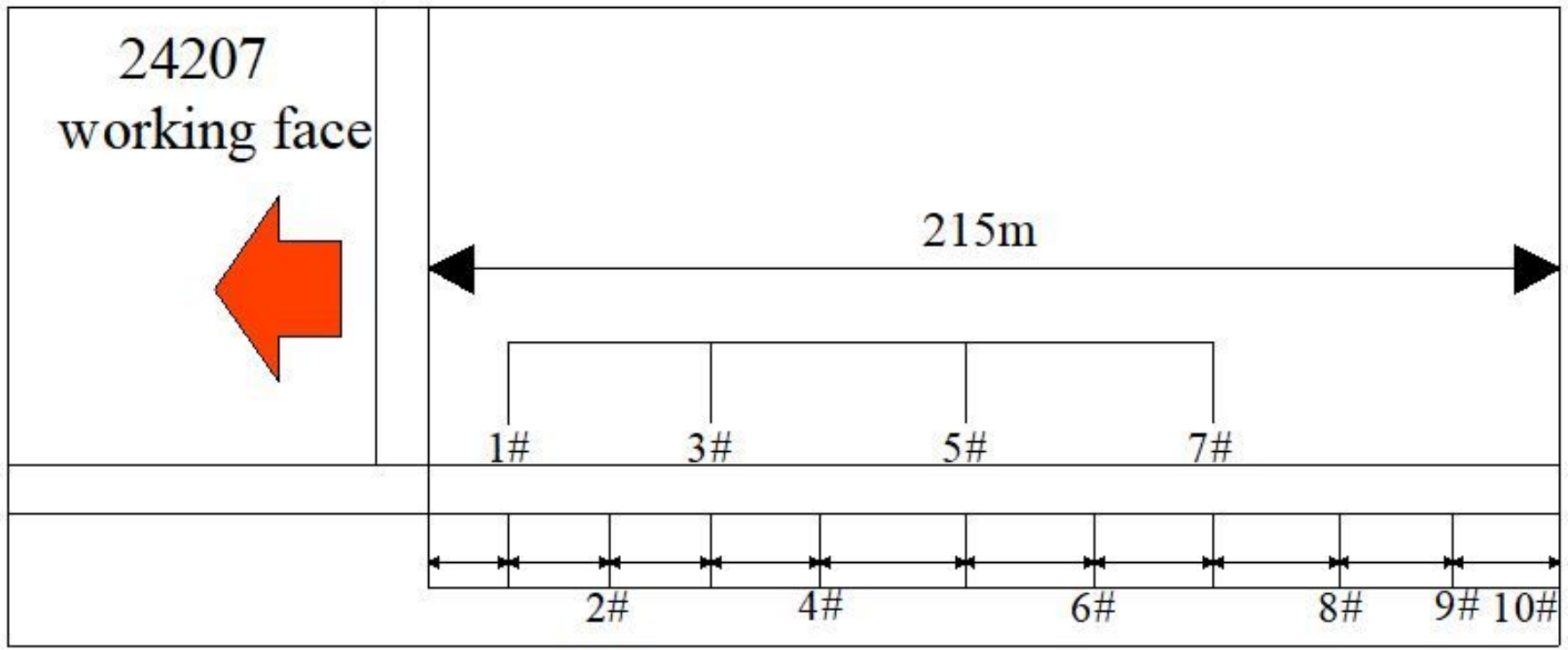

Figure 9

Layout of measuring station for 24207 gob-side entry retaining 


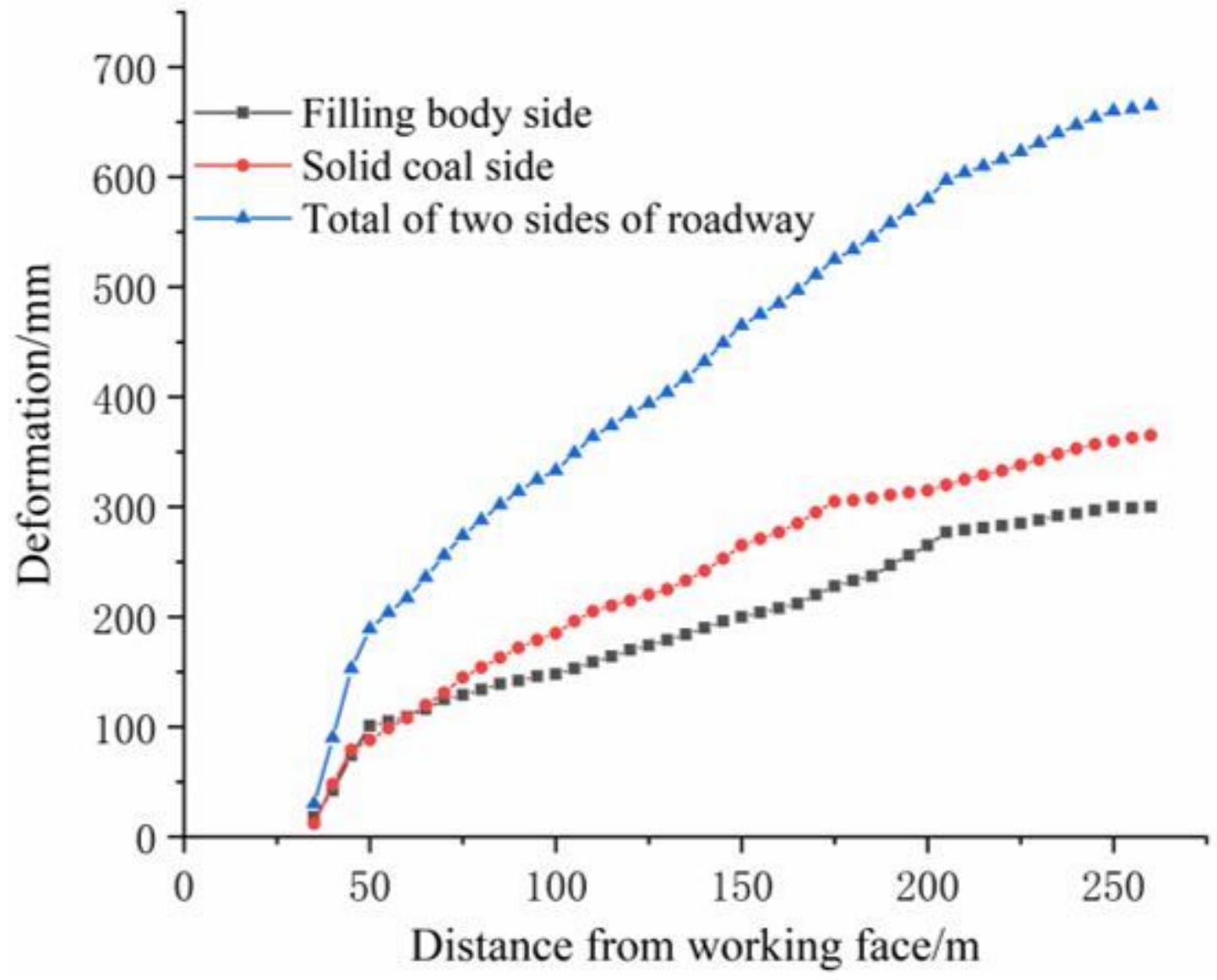

Figure 10

Deformation curve of two sides of 24207 gob-side entry retaining 


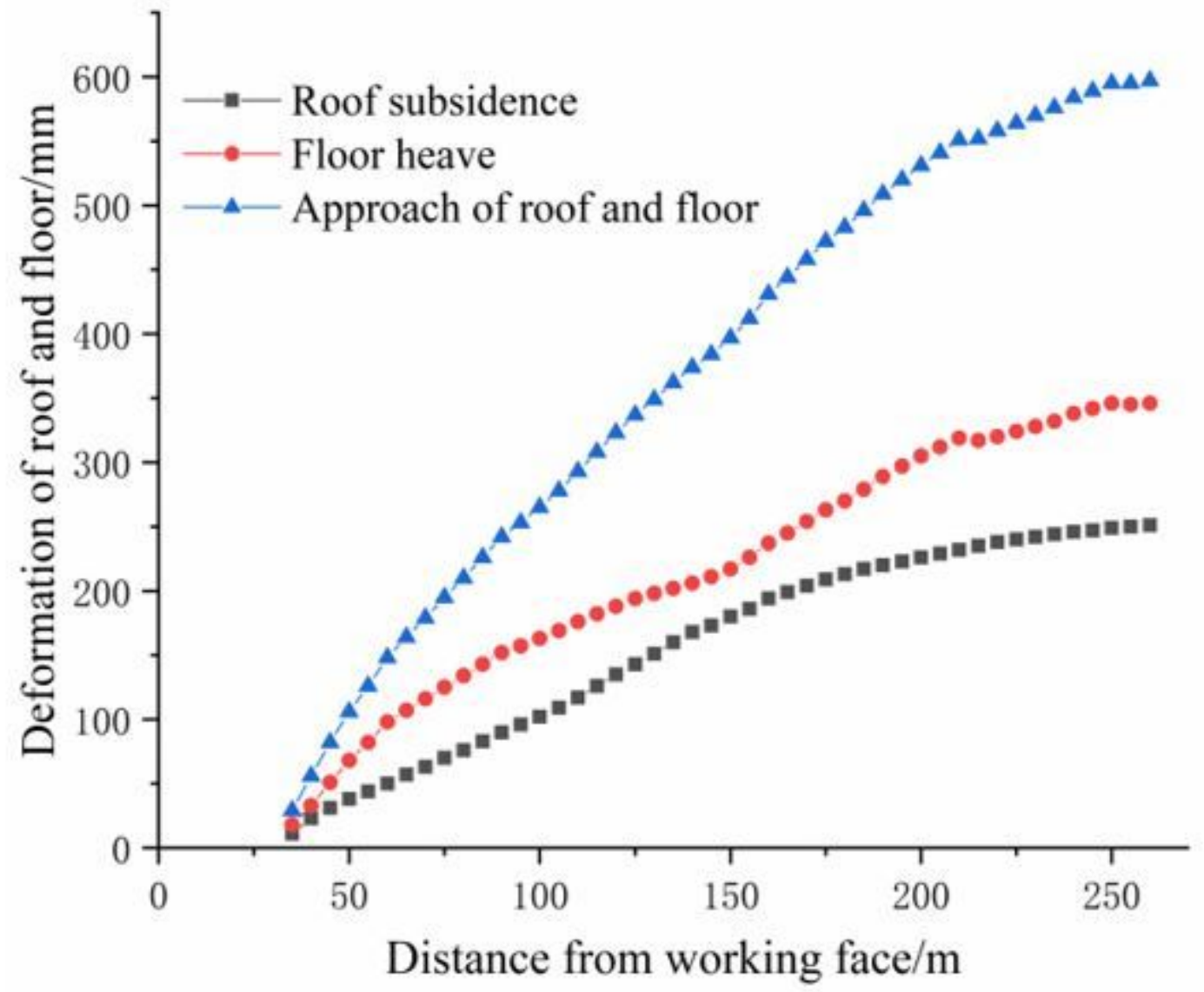

Figure 11

Curve of roof and floor deformation of 24207 gob-side entry retaining 


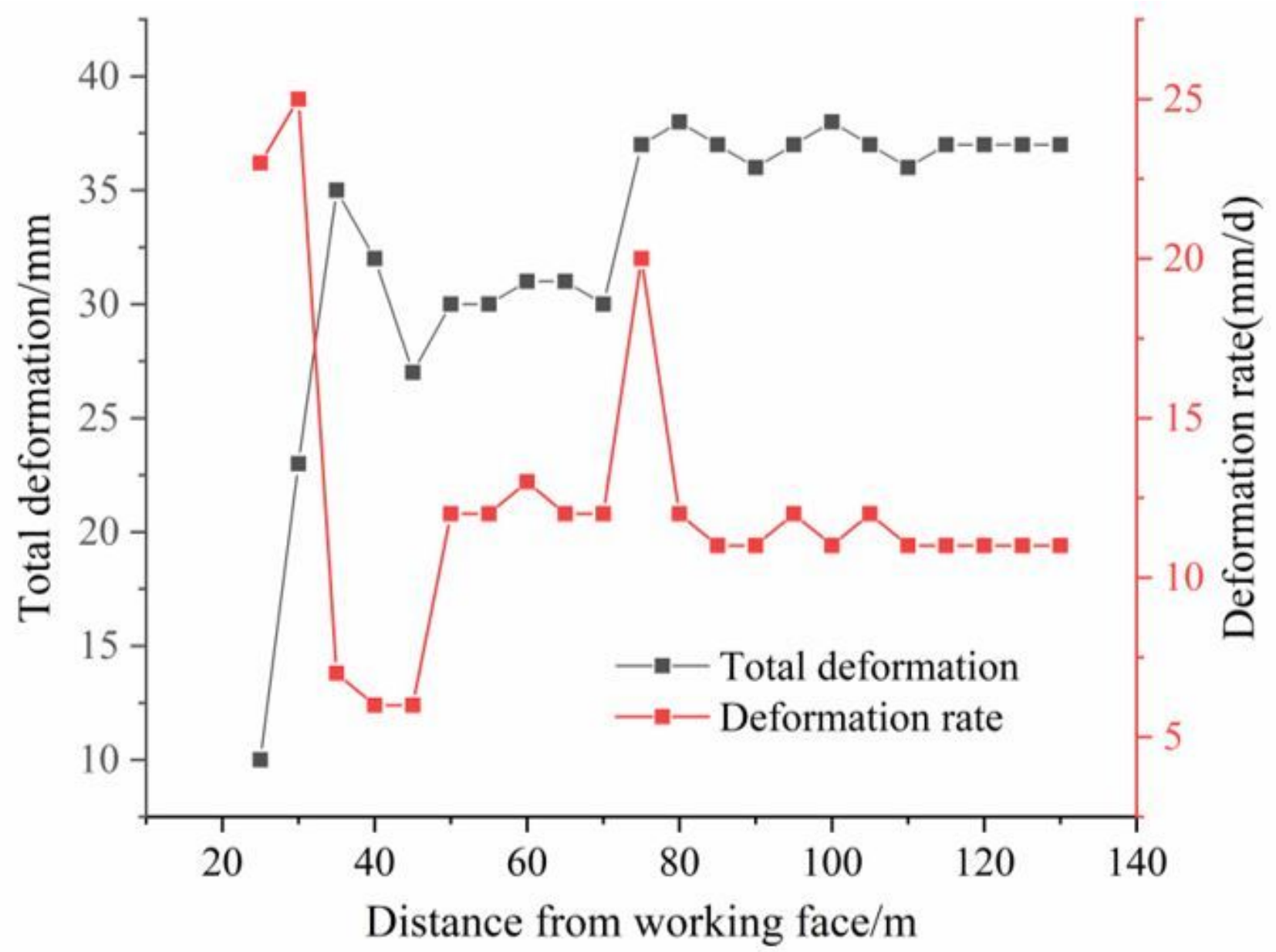

Figure 12

Relationship curve between deformation of filling body and distance from working face in 24207 gobside entry retaining 